\title{
Petrography and petrology of the Hawaii Scientific Drilling Project lavas: Inferences from olivine phenocryst abundances and compositions
}

\author{
Michael B. Baker \\ Division of Geological and Planetary Sciences, California Institute of Technology, Pasadena \\ Sophie Alves \\ Institut de Physique du Globe de Paris \\ Edward M. Stolper \\ Division of Geological and Planetary Sciences, California Institute of Technology, Pasadena
}

\begin{abstract}
The Mauna Loa (ML) and Mauna Kea (MK) lavas recovered by the Hawaii Scientific Drilling Project (HSDP) include aphyric to highly olivine-phyric basalts. The average olivine phenocryst abundance in the reference suite of ML flows is $14.5 \mathrm{vol} \%$ (vesicle-free and weighted by the flow thickness), while the average abundances of olivine in the reference suites of the MK alkalic and tholeiitic basalts are 1.1 and $14.0 \mathrm{vol} \%$, respectively. Plagioclase and augite phenocrysts are rare in the ML and MK tholeiites, but the MK alkalic basalts can have up to 4 vol \% plagioclase phenocrysts. Strained olivine grains, thought to represent disaggregated dunite xenoliths from the cumulate pile within the magma chamber(s), are ubiquitous in the drill core lavas. These deformed grains can comprise up to $50 \%$ of the modal olivine in a given rock. Olivine core compositions in the lavas span forsterite contents of 80.4-90.7 (median 88.8, ML tholeiites), 75.8-86.6 (median 85.8, MK alkalic basalts), and 76.3-90.5 (median $88.0 \mathrm{~mol} \%$, MK tholeiites). Olivines with core compositions in the range Fo89-90.5 are present in tholeiitic lavas with a wide range of whole-rock $\mathrm{MgO}$ contents (9-30 wt \%). Strained and unstrained olivines completely overlap in composition as do the compositions of spinels $(100 * \mathrm{Cr} /(\mathrm{Cr}+\mathrm{Al}) \sim 59-72 ; \mathrm{Mg} \#$ $\left.=100^{*} \mathrm{Mg} /\left(\mathrm{Mg}+\mathrm{Fe}^{2+}\right) \sim 40-66\right)$ present as inclusions in the olivine phenocrysts. The presence of Fo90.5 olivine in the HSDP lavas requires magmas with $\sim 16 \mathrm{wt} \% \mathrm{MgO}$ in the ML and MK plumbing systems. Rare dunite xenoliths are also present in the drill core lavas. While compositionally homogeneous within a given xenolith, the six xenoliths contain olivines that span a wide range of forsterite contents (78.3-89.2 mol \%). Spinels in these xenoliths are chrome-rich, have $\mathrm{Mg \#}$ between 31 and 66, and define two populations on the basis of $\mathrm{TiO}_{2}$ contents. Whole-rock compositions for the ML and MK tholeiites define olivine control lines on MgO-oxide diagrams, and the relationship between whole-rock $\mathrm{MgO}$ and olivine phenocryst abundance in these lavas suggests that the lavas with $>12 \mathrm{wt} \% \mathrm{MgO}$ have accumulated olivine. Comparing the weighted bulk composition of all of the MK tholeiites in the drill core with a calculated parental magma suggests that, on average, the MK tholeiites entrained most of the olivine phenocrysts that crystallized from their parental liquids. Although deformed olivines in Hawaiian lavas are widely thought to represent disaggregated dunite xenoliths, none of the major- or minor-element data on the strained or unstrained olivine phenocrysts suggest that the strained olivines in the HSDP lavas are exotic. We suggest that most of the olivine phenocrysts in a given flow, whether strained or unstrained, are closely related to the evolved liquid that now forms the groundmass. This is consistent with observed correlations between isotopic systems measured on olivine separates (e.g., $\mathrm{O}, \mathrm{He}$ ) and isotopic systems dominated by groundmass (e.g., $\mathrm{Nd}, \mathrm{Pb}$ ).
\end{abstract}

\section{Introduction}

The first phase of the Hawaii Scientific Drilling Project (HSDP) core-drilled to a depth of $1,056 \mathrm{~m}$ at a site just east of downtown Hilo. The upper $\sim 280 \mathrm{~m}$ of the core contains 27 flows from Mauna Loa volcano (ML) and sequences of calcare-

Copyright 1995 by the American Geophysical Union.

Paper number 96JB00180.

0148-227/95/96JB-00180\$09.00 ous and volcaniclastic sediments [Hawaii Scientific Drilling Project (HSDP), 1994]. The lower $\sim 776 \mathrm{~m}$ of the core comprises 184 identified flows from Mauna Kea volcano (MK). The boundary between ML and MK lavas is well-defined based on the major- and trace-element and isotopic compositions of the lavas [Eiler et al., this issue; Hauri et al., this issue; Hofmann and Jochum, this issue; Kurz et al., this issue; Lassiter et al., this issue; Rhodes, this issue]. The abundance of olivine phenocrysts is a striking characteristic of the lavas from the HSDP core-more than $60 \%$ of the sampled flows contain $>5 \mathrm{vol} \%$ olivine phenocrysts and $10 \mathrm{wt} \% \mathrm{MgO}$, and some have more than 40 vol \% olivine (on a vesicle-free ba- 
sis). In contrast, only $\sim 20 \%$ of surface-sampled ML tholeiites compiled by Wilkinson [1991] are comparably rich in olivine and $\mathrm{MgO}$.

Many olivine phenocrysts from the HSDP core display deformational features similar to those observed in olivines from other Hawaiian lavas [e.g., Clague and Denlinger, 1994; Garcia et al., 1995; Helz, 1987; Wilkinson and Hensel, 1988; Yang et al., 1994]. These strained olivines have been interpreted as disaggregated cumulate dunites [e.g., Clague and Denlinger, 1994; Helz, 1987]. The characteristics and origin of these strained olivines are important in understanding the compositional variations of the HSDP lavas since, like all Hawaiian lava series [e.g., Wright, 1971], olivine control lines define the compositional variation of lavas with $>8 \mathrm{wt} \%$ $\mathrm{MgO}$. Understanding chemical and isotopic variability along these olivine control lines will depend on whether the olivine phenocrysts are dominantly xenocrysts that are distantly related or unrelated to the drill core lavas, or cognate crystals that grew from the host liquid or closely-related liquids.

This paper summarizes the microscopic petrography of most of the 90 flows sampled as a reference suite for majorand trace-element and isotopic analysis. Our analytical work focused on the compositions of olivines and their spinel inclusions from a subset of the flows. We also determined the compositions of olivines and spinels in six centimeter-sized dunite xenoliths from five MK tholeiite flows. In our analytical work, we looked for chemical distinctions between strained and unstrained olivine phenocrysts, between the spinel inclusions in the two types of olivines, and between phenocrysts and phases in the xenoliths. Using modal and compositional data for olivines, we evaluated the extent to which olivine accumulation affected the compositions of the drill core lavas. We also calculated the composition of a liquid that could be in equilibrium with the most forsteritic olivines found in the MK tholeiites $\left(\mathrm{FO}_{90} \mathrm{~S}_{5}\right.$-this composition could represent a parental liquid to the suite of sampled tholeiitic lavas. Finally, we compared the composition of the parental liquid to the weighted bulk composition of all of the tholeiitic lavas in the MK portion of the drill core.

\section{Analytical Techniques}

Between 1000-1500 points were counted on each petrographic thin section $\left(\sim 10^{3} \mathrm{~mm}^{2}\right)$, and these data were used to determine the relative areas of minerals in the sections. Following Chayes [1956], we present our modal data on a volume percent basis. We use the term "phenocryst" to indicate "a relatively large, conspicuous crystal in a porphyritic rock" [Bates and Jackson, 1987] and the terms "cognate" and "exotic" or "xenocryst" to signify genetic interpretations. We selected a size of $0.7 \mathrm{~mm}$ in longest dimension as the boundary between phenocrysts and groundmass. We did not distinguish strained and unstrained olivine grains in our modal analysis, but it is rare to find a thin section that does not contain some deformed olivines. Information on the relative proportions of strained and unstrained olivine grains in the HSDP rocks is presented by Garcia [this issue].

Compositions of olivines and their spinel inclusions were determined with the five-spectrometer JEOL 733 electron microprobe at the California Institute of Technology (Caltech) using a $15 \mathrm{keV}$ accelerating voltage, a 20-25 nA beam current, a 1- $\mu \mathrm{m}$ spot size, and mineral and oxide standards. Data were reduced using a modified ZAF procedure (CITZAF, [Armstrong,
1988]). San Carlos olivine was analyzed at the beginning and end of each probe session; based on 48 analyses, the percentage uncertainties $(100 * 1 \sigma /$ mean; all uncertainties are $1 \sigma$ unless otherwise stated) for $\mathrm{SiO}_{2}, \mathrm{FeO}, \mathrm{MgO}, \mathrm{CaO}$, and $\mathrm{NiO}$ are $1.0 \%, 2.4 \%, 0.9 \%, 10 \%$, and $6 \%$, respectively. Our average $\mathrm{CaO}$ content of San Carlos olivine $(0.10 \pm 0.01$ wt \%) agrees with high precision analyses of this standard done at Caltech (J.T. Armstrong, personal communication, 1995). The propagated uncertainty in the molar $100 * \mathrm{Mg} /\left(\mathrm{Mg}^{2} \mathrm{Fe}^{2+}\right)$ value (i.e., in the $\mathrm{Mg} \#$ or Fo-content of an olivine) is \pm 0.23 .

\section{Results}

\section{Petrography}

Modes are reported in Table 1. Flows from the ML and MK sections of the drill core vary from aphyric $(<1$ vol \% phenocrysts) to highly olivine phyric (up to $\sim 45$ vol $\%$ olivine; all abundances of crystalline phases and groundmass are on a vesicle-free basis). In the ML samples, olivine abundances are $0.5-38$ vol $\%$, and $\sim 70 \%$ of the samples contain $\geq 10$ vol $\%$ olivine phenocrysts. The weighted abundance of olivine phenocrysts in the ML reference suite is 14.5 vol \% (weighted by flow thickness after correcting for the vesicle content of each flow). Olivine abundances are $0-1.4$ vol \% in the MK alkalic basalts and $0.2-46$ vol \% in the MK tholeiitic basalt flows; $\sim 40 \%$ of the tholeiitic lavas contain $\geq 10$ vol $\%$ olivine. The weighted olivine abundance in the MK reference suite (both alkalic basalts and tholeiites) is $13.0 \mathrm{vol} \%$; the weighted proportion of olivine in just the tholeiitic flows is $14.0 \mathrm{vol}$ $\%$. Downhole variation in olivine phenocryst abundance is shown in Figure 1. There is no systematic variation in olivine content with depth in the ML or MK tholeiite suites.

Spinel inclusions are found in olivine phenocrysts throughout the drill core. Plagioclase and augite phenocrysts are rare in the ML flows and in the MK tholeiitic basalt flows; when present, their abundances are generally each less than $1-2$ vol \% (Table 1). Groundmass consists of plagioclase, pyroxene, olivine, chromian spinel, Fe-Ti oxides, and interstitial glass, and textures vary from intergranular, to intersertal, to subophitic. Orthopyroxene is present in the groundmass of some of the ML flows (microphenocrysts in the size category used by Garcia [this issue]) but has not been observed in the MK tholeiites. The vesicularity of the lavas varies dramatically from flow to flow and even within individual flows [HSDP, 1994]; based on point counts of the thin sections, vesicles contents are $<1$ to $\sim 38$ vol $\%$ (Table 1 ), with a median value of $\sim 8$ vol $\%$.

Olivine phenocrysts are generally equant to tabular and subhedral to euhedral. Most are $\leq 5 \mathrm{~mm}$ in longest dimension, but rare centimeter-sized olivine megacrysts are present in some ML flows. In addition to spinel inclusions, some olivines contain melt inclusions (usually $200-400 \mu \mathrm{m}$ in diameter) consisting of skeletal pyroxene, glass, and generally the outline of a vapor bubble. ML and MK tholeites also contain rare olivines with coarsely skeletal morphologies that we interpret as resorption features, although these morphologies may reflect rapid growth. These grains are typically $<2 \mathrm{~mm}$ in longest dimension. Sections with skeletal olivines can also contain larger ( $>2 \mathrm{~mm}$ ) grains with crenulate grain boundaries. The subhedral to euhedral olivine phenocrysts as well as those displaying coarsely skeletal morphologies and crenulate grain boundaries occur in thin section as "normal" (or unstrained) 
Table 1. Phenocryst Abundances in the Hawaii Scientific Drilling Project Lavas

\begin{tabular}{|c|c|c|c|c|c|c|c|}
\hline Thin section & Unit & $\begin{array}{l}\text { Depth } \\
\text { (m) }\end{array}$ & $\begin{array}{c}\mathrm{MgO} \\
\text { (wt \%) }\end{array}$ & $\begin{array}{c}\text { Oliv } \\
\text { (vol \%) }\end{array}$ & $\begin{array}{c}\text { Plag } \\
\text { (vol \%) }\end{array}$ & $\underset{\text { (vol \%) }}{\text { Aug }}$ & $\begin{array}{c}\text { Ves } \\
\text { (vol \%) }\end{array}$ \\
\hline & & & $M L$ Lavg & & & & \\
\hline R55-1.0D & 11 & 74.1 & 12.3 & 8.0 & 0.0 & 0.0 & 3.9 \\
\hline R68-1.25B & 13 & 94.1 & 30.3 & 32.4 & 0.3 & 0.0 & 15.4 \\
\hline R75-4.3D & 14 & 105.6 & 12.0 & 11.6 & 0.4 & 0.2 & 4.5 \\
\hline R83-3.7D & 15 & 117.6 & 17.6 & 23.2 & 0.0 & 0.2 & 0.5 \\
\hline R91-2.3D & 15 & 129.2 & 20.0 & 15.9 & 0.0 & 0.0 & 9.0 \\
\hline R96-1.80 & 16 & 136.7 & 18.9 & 18.4 & 0.0 & 0.0 & 2.8 \\
\hline R103-3.5B & 17 & 148.0 & 18.9 & 14.4 & 0.1 & 0.0 & 3.9 \\
\hline R108-4.7D & 19 & 156.0 & 9.6 & 0.6 & 0.0 & 0.0 & 8.1 \\
\hline R110-3.1D & 20 & 161.6 & 10.9 & 0.5 & 0.0 & 0.0 & 14.1 \\
\hline R111-4.3D & 21 & 165.0 & 9.2 & 0.3 & 0.0 & 0.0 & 37.5 \\
\hline R114-3.5D & 23 & 176.1 & 12.5 & 2.1 & 0.0 & 0.0 & 7.9 \\
\hline R117-2.2D & 27 & 184.8 & 7.0 & 0.5 & 5.2 & 0.5 & 18.5 \\
\hline R121-2.45B & 28 & 191.8 & 14.8 & 14.2 & 0.0 & 0.0 & 1.5 \\
\hline R121-3.55B & 28 & 192.1 & & 16.1 & 0.0 & 0.0 & 1.7 \\
\hline R126-0.90B & 29 & 199.8 & 15.3 & 10.2 & 0.0 & 0.0 & 4.7 \\
\hline $\mathrm{R} 126-2.00 \mathrm{~B}$ & 29 & 200.1 & & 10.1 & 0.0 & 0.0 & 4.9 \\
\hline R128-0.45B & 30 & 205.7 & 26.5 & 32.7 & 0.0 & 0.0 & 16.9 \\
\hline R128-1.45B & 30 & 206.0 & & 31.7 & 0.0 & 0.0 & 6.8 \\
\hline R129-5.50D & 32 & 210.8 & 21.9 & 27.7 & 0.0 & 0.0 & 4.8 \\
\hline R130-3.50D & 32 & 213.2 & & 27.1 & 0.0 & 0.0 & 9.6 \\
\hline R133-7.0B & 34 & 223.4 & 17.0 & 23.1 & 0.0 & 0.0 & 0.8 \\
\hline R133-7.85B & 34 & 223.7 & & 13.2 & 0.0 & 0.0 & 0.9 \\
\hline $\mathrm{R} 135-6.0 \mathrm{~B}$ & 35 & 229.5 & 17.9 & 21.5 & 0.0 & 0.0 & 21.7 \\
\hline R142-6.8 & 37 & 242.7 & 13.1 & 18.2 & 0.0 & 0.0 & 8.4 \\
\hline R150-0.05B & 40 & 260.0 & 15.4 & 15.4 & 0.0 & 0.0 & 9.1 \\
\hline \multirow[t]{2}{*}{ R153-6.00B } & 43 & 269.1 & 14.9 & 14.3 & 0.1 & 0.1 & 1.5 \\
\hline & & & MK Lave & & & & \\
\hline R158-0.05B & 45 Alk & 281.3 & 11.4 & 2.2 & 0.0 & 0.0 & 5.3 \\
\hline R158-0.05B & 45 Alk & 281.3 & & 2.0 & 0.0 & 0.0 & 4.5 \\
\hline R159-4.10B & 47 Alk & 285.5 & 8.7 & 1.1 & 0.0 & 0.0 & 29.3 \\
\hline R160-6.8B & 47 Alk & 289.3 & & 9.3 & 0.0 & 0.0 & 18.9 \\
\hline R164-1.55B & 49 Alk & 299.3 & 6.2 & 0.0 & 3.9 & 0.0 & 0.5 \\
\hline R164-1.95B & 49 Alk & 299.3 & & 0.3 & 3.2 & 0.0 & 1.0 \\
\hline R166-5.25B & 51 Alk & 305.8 & 6.2 & 0.0 & 0.5 & 0.0 & 14.4 \\
\hline R166-6.30D & 51 Alk & 306.1 & & 0.0 & 0.0 & 0.0 & 24.8 \\
\hline R167-1.30B & $52 \mathrm{Alk}$ & 307.7 & 6.4 & 0.1 & 0.0 & 0.0 & 10.2 \\
\hline R168-7.75B & 53 & 312.8 & 8.2 & 1.2 & 0.1 & 1.7 & 16.3 \\
\hline R168-8.45B & 53 & 313.0 & & 1.2 & 0.1 & 0.9 & 14.2 \\
\hline R169-3.55B & 54 & 314.5 & 7.4 & 2.6 & 0.0 & 0.2 & 18.0 \\
\hline R169-5.20B & 54 & 315.0 & & 1.5 & 0.0 & 0.0 & 15.8 \\
\hline R171-4.55B & 55 & 320.5 & 14.4 & 14.3 & 0.4 & 1.4 & 15.6 \\
\hline R171-5.65D & 55 & 320.9 & & 12.6 & 0.3 & 1.3 & 10.6 \\
\hline R174-1.20B & 57 Alk & 324.8 & 5.5 & 0.0 & 0.2 & 0.0 & 31.0 \\
\hline R174-2.65B & 57 Alk & 325.3 & & 0.1 & 0.7 & 0.0 & 16.8 \\
\hline R180-5.90D & 59 & 342.0 & 8.9 & 5.7 & 0.0 & 0.0 & 5.1 \\
\hline R180-7.00D & 59 & 342.4 & & 9.1 & 0.0 & 0.0 & 11.3 \\
\hline R185-3.95B & 62 & 354.5 & 7.5 & 0.6 & 0.0 & 0.0 & 2.3 \\
\hline $\mathrm{R} 185-4.6 \mathrm{~B}$ & 62 & 354.7 & & 0.6 & 0.0 & 0.0 & 1.8 \\
\hline R189-8.5B & 64 & 367.6 & 28.7 & 40.8 & 0.0 & 0.0 & 11.4 \\
\hline R189-9.2B & 64 & 367.8 & & 41.6 & 0.0 & 0.3 & 8.6 \\
\hline R193-3.9B & 69 & 378.3 & 21.7 & 22.0 & 0.0 & 0.0 & 24.6 \\
\hline R193-4.5B & 69 & 378.5 & & 24.1 & 0.0 & 0.0 & 17.1 \\
\hline R197-0.8B & 70 & 389.4 & 24.1 & 35.3 & 0.0 & 0.0 & 9.4 \\
\hline R197-1.5B & 70 & 389.7 & & 43.7 & 0.0 & 0.0 & 4.9 \\
\hline R202-1.9B & 72 & 400.5 & 7.5 & 3.9 & 0.0 & 0.0 & 0.3 \\
\hline $\mathrm{R} 202-2.0 \mathrm{~B}$ & 72 & 400.5 & & 3.4 & 0.0 & 0.0 & 0.0 \\
\hline R208-5.2B & 75 & 415.7 & 10.1 & 6.5 & 0.0 & 0.1 & 1.6 \\
\hline R208-5.9B & 75 & 415.9 & & 2.3 & 0.0 & 0.6 & 0.9 \\
\hline R212-0.8B & 76 & 424.2 & 22.6 & 27.2 & 0.0 & 0.0 & 10.3 \\
\hline R212-1.4B & 76 & 424.4 & & 32.6 & 0.0 & 0.0 & 7.4 \\
\hline R214-3.0B & 78 & 429.4 & 8.5 & 4.6 & 0.0 & 0.0 & 4.5 \\
\hline R214-4.0B & 78 & 429.7 & & 4.7 & 0.0 & 0.0 & 3.3 \\
\hline R215-7.2B & 80 & 433.8 & 24.4 & 35.2 & 0.0 & 0.0 & 7.7 \\
\hline $\mathrm{R} 215-8.0 \mathrm{~B}$ & 80 & 434.0 & & 35.7 & 0.0 & 0.0 & 9.7 \\
\hline
\end{tabular}


Table 1. (continued)

\begin{tabular}{|c|c|c|c|c|c|c|c|}
\hline Thin section & Unit & $\begin{array}{l}\text { Depth } \\
\text { (m) }\end{array}$ & $\underset{(\mathbf{w t} \%)}{\mathrm{MgO}}$ & $\underset{\text { (vol \%) }}{\text { Oliv }}$ & $\begin{array}{c}\text { Plag } \\
\text { (vol \%) }\end{array}$ & $\underset{(\text { vol \%) }}{\text { Aug }}$ & $\begin{array}{l}\text { Ves } \\
(\text { vol \%) }\end{array}$ \\
\hline R221-4.4B & 88 & 451.2 & 7.4 & 1.4 & 0.0 & 0.0 & 2.2 \\
\hline R221-7.9B & 88 & 452.3 & & 0.1 & 0.0 & 0.0 & 1.9 \\
\hline R224-2.8B & 89 & 459.7 & 9.0 & 5.3 & 0.2 & 0.0 & 0.9 \\
\hline R225-3.35B & 89 & 463.0 & & 4.0 & 0.0 & 0.0 & 1.3 \\
\hline R229-1.75B & 91 & 473.2 & 13.7 & 14.8 & 0.0 & 0.1 & 6.3 \\
\hline R233-4.15B & 96 & 485.5 & 14.3 & 17.5 & 0.0 & 0.0 & 11.5 \\
\hline R233-4.85B & 96 & 485.8 & & 14.5 & 0.2 & 0.0 & 13.3 \\
\hline R234-7.4B & 97 & 489.6 & 13.2 & 18.8 & 0.0 & 0.0 & 11.0 \\
\hline R234-9.75B & 97 & 490.4 & & 16.8 & 0.0 & 0.0 & 9.0 \\
\hline R243-8.4B & 103 & 513.3 & 20.3 & 32.3 & 0.0 & 0.0 & 6.2 \\
\hline R243-8.6B & 103 & 513.4 & & 31.9 & 0.0 & 0.0 & 7.1 \\
\hline R246-5.5B & 105 & 520.2 & 15.9 & 17.4 & 0.0 & 0.0 & 12.5 \\
\hline R246-5.9B & 105 & 520.3 & & 17.2 & 0.2 & 0.0 & 11.2 \\
\hline R247-0.4B & 105 & 520.7 & & 4.5 & 9.3 & 1.4 & 17.7 \\
\hline $\mathrm{R} 250-0.0 \mathrm{~B}$ & 106 & 526.6 & 14.9 & 14.1 & 0.0 & 0.0 & 1.6 \\
\hline R250-1.55B & 106 & 527.1 & & 16.7 & 0.0 & 0.0 & 4.0 \\
\hline R251-3.9B & 107 & 530.9 & 8.4 & 3.1 & 0.0 & 0.0 & 19.3 \\
\hline $\mathrm{R} 251-4.6 \mathrm{~B}$ & 107 & 531.1 & & 3.8 & 0.0 & 0.0 & 13.8 \\
\hline R259-0.75B & 109 & 542.2 & 20.9 & 26.5 & 0.0 & 0.0 & 10.7 \\
\hline R259-1.85B & 109 & 542.5 & & 25.1 & 0.0 & 0.0 & 8.0 \\
\hline R286-0.9B & 118 & 590.1 & 18.5 & 19.4 & 0.0 & 0.0 & 11.3 \\
\hline R286-2.2B & 118 & 590.5 & & 27.0 & 0.0 & 0.0 & 10.4 \\
\hline R287-3.15B & 119 & 594.1 & 7.8 & 0.2 & 0.2 & 0.1 & 22.7 \\
\hline R287-4.7B & 119 & 594.6 & & 0.7 & 0.0 & 0.2 & 25.4 \\
\hline R291-0.3B & 120 & 603.9 & 11.4 & 7.5 & 0.0 & 0.7 & 11.7 \\
\hline R291-1.45B & 120 & 604.2 & & 9.9 & 0.0 & 0.4 & 8.8 \\
\hline R298-0.75B & 125 & 615.8 & 11.9 & 11.3 & 0.0 & 0.1 & 4.4 \\
\hline R298-1.85B & 125 & 616.1 & & 9.5 & 0.0 & 0.1 & 4.1 \\
\hline R303-4.45B & 126 & 623.8 & 20.6 & 29.8 & 0.0 & 0.0 & 2.9 \\
\hline R311-1.8B & 131 & 645.4 & 10.3 & 1.1 & 0.0 & 0.0 & 25.8 \\
\hline R315-4.85B & 132 & 658.6 & 15.4 & 18.5 & 0.0 & 0.0 & 1.8 \\
\hline R333-3.30B & 144 & 704.9 & 16.9 & 17.6 & 0.0 & 0.0 & 9.3 \\
\hline R340-5.15B & 147 & 720.3 & 15.6 & 15.3 & 0.0 & 0.0 & 2.9 \\
\hline R365-0.05B & 159 & 781.2 & 22.7 & 30.7 & 0.0 & 0.0 & 4.0 \\
\hline R385-8.3B & 170 & 836.5 & 8.4 & 5.8 & 0.1 & 0.0 & 3.6 \\
\hline R424-9.3B & 196 & 939.1 & 10.9 & 0.1 & 0.0 & 0.0 & 33.8 \\
\hline R442-5.7B & 208 & 985.0 & 21.6 & 28.5 & 0.0 & 0.0 & 6.4 \\
\hline R463-9.3B & 224 & 1044.7 & 12.0 & 2.2 & 0.0 & 0.0 & 23.5 \\
\hline
\end{tabular}

Mineral proportions and vesicle abundances are based on $>1000$ points per thin section; all phases $<0.7$ mm were counted as part of the groundmass. No distinction was made between strained and unstrained olivine grains. Whole-rock MgO content for each flow from Rhodes [this 1ssue]. Abbreviations are Oliv, olivine; Plag, plagioclase; Aug, augite; Ves, vesicles; Alk, alkalic basalt. Undesignated units are tholeistes. Groundmass $(\mathrm{vol} \%)=100-$ reported mineral and vesicle abundances.

grains and as strained olivines that display "wavy" or kinkbanded extinction (see Helz [1987] and Garcia [this issue] for detailed descriptions and photomicrographs of deformed olivines in Hawaiian lavas). Every thin section containing more than $\sim 1$ vol $\%$ olivine phenocrysts contains some strained olivine grains. However, no other textural distinctions have been observed between strained and unstrained olivines. In some ML and MK tholeiite lavas, elongate olivines (length/width $>10-15$ ) comprise $<20 \%$ of the total olivine phenocryst population (see Garcia [this issue]). Their morphology is similar to the chain olivines described by Donaldson [1976], but they are not internally skeletal. We have not observed strain features in any of these elongate olivines.

Figure 2 shows modal olivine abundance (based on thin section point counts) versus whole-rock MgO content [Rhodes, this issue]. The data for the MK HSDP samples agrees with the modal data of Frey et al. [1991] and Yang et al. [1994] for dredged Mauna Kea lavas (Figure 2b). Above 12-13 wt \% $\mathrm{MgO}, \mathrm{ML}$ and MK tholeiites display positive, approximately linear correlations between $\mathrm{MgO}$ content and modal olivine. For $\mathrm{MgO}$ contents less than $\sim 12$ wt $\%$, ML and MK lavas contain $\leq 10$ vol $\%$ olivine phenocrysts, and most lavas with $<10$ wt $\% \mathrm{MgO}$ contain $<5$ vol \% olivine phenocrysts. Based on the regression lines in Figure 2, MgO contents at $0 \%$ olivine are 7.7 and $7.2 \mathrm{wt} \%$, respectively for the ML and MK tholeiites. ML and MK tholeiites with 11-13 wt \% $\mathrm{MgO}$ are the most magnesian lavas with olivine modes $\leq 10$ vol $\%$. For each volcano, we averaged these low-olivine, high-MgO lavas (two from ML and four from MK) and list the two mean compositions in Table 2. These two average compositions are taken to represent the most primitive "liquids" in the HSDP core, and calculations asing $\mathrm{MK}_{11.5}$ are described in the discussion section.

Dunite xenoliths are present but uncommon in the HSDP core and in tholeiitic lavas from other Hawaiian volcanoes 


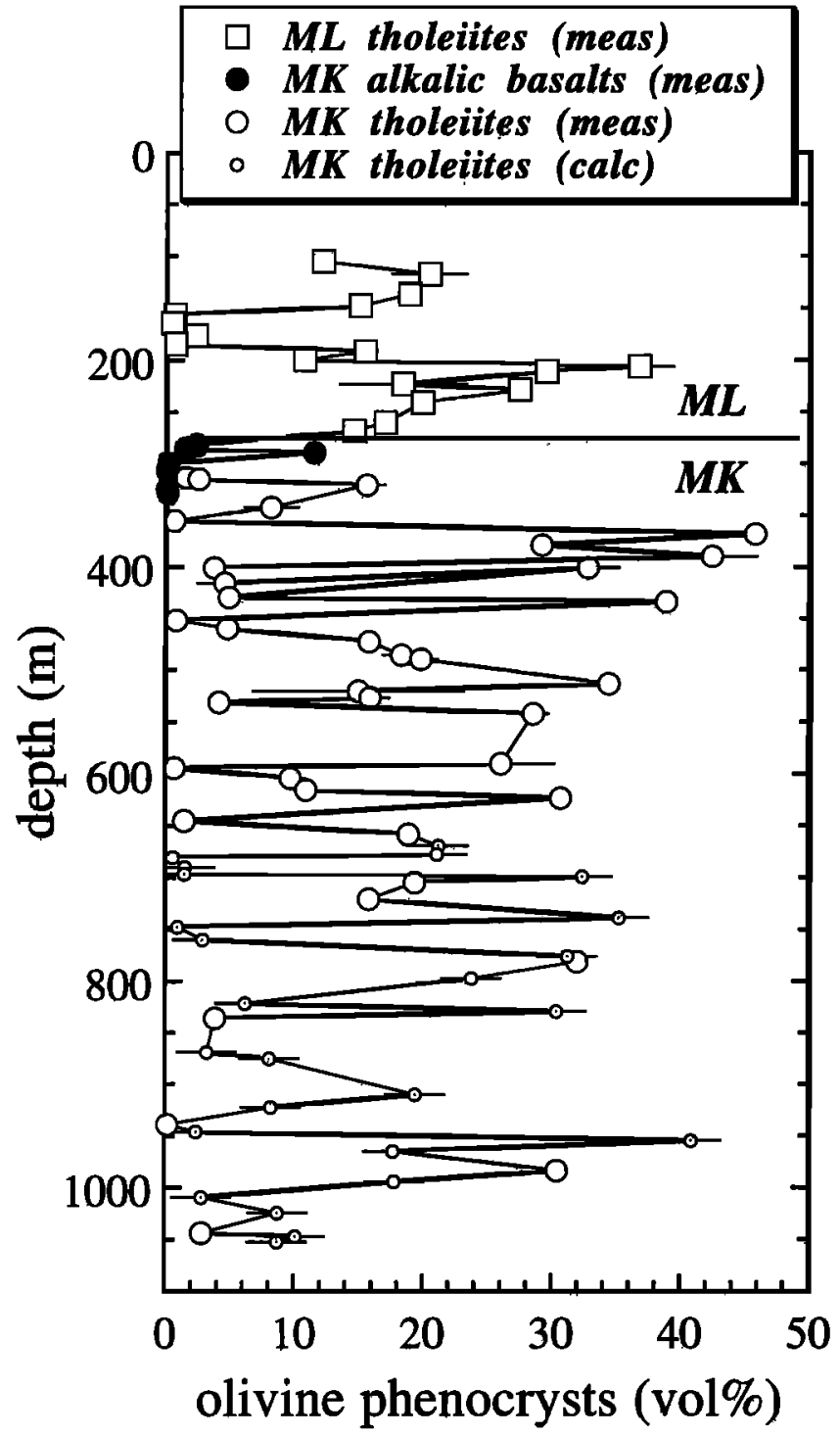

Figure 1. Volume percent of olivine grains $20.7 \mathrm{~mm}$ in longest dimension in each thin section versus stratigraphic height in the HSDP drill core. The plotted abundances include both strained and unstrained olivine grains and are normalized to a vesicle-free basis. Measured abundances are based on $>1000$ points per thin section. Some MK points are calculated based on whole-rock MgO content [Rhodes, this issue]; see caption to Figure 2 for the equation used to calculate these olivine contents. Mean uncertainties on the calculated points are $3 \mathrm{vol} \%$ (absolute) and are given by the horizontal bars. Horizontal bars associated with some of the measured values indicate the total range found in two thin sections from the same unit; symbols indicate average modal olivine abundances for these units. Modal data for three thin sections were averaged for unit 105 and the horizontal bar equals $1 \sigma$.

[Clague, 1987; Jackson, 1968]. The small number of dunites contrasts with the common occurrence of centimeter-sized gabbroic xenoliths in both the ML and MK sections of the core [HSDP, 1994]. Six dunite xenoliths (1-3 cm in size) were extracted from tholeiitic flows in the MK portion of the core (sample locations are given in the footnotes to Table 3); these samples represent most of the larger (>1 cm-sized) dunite

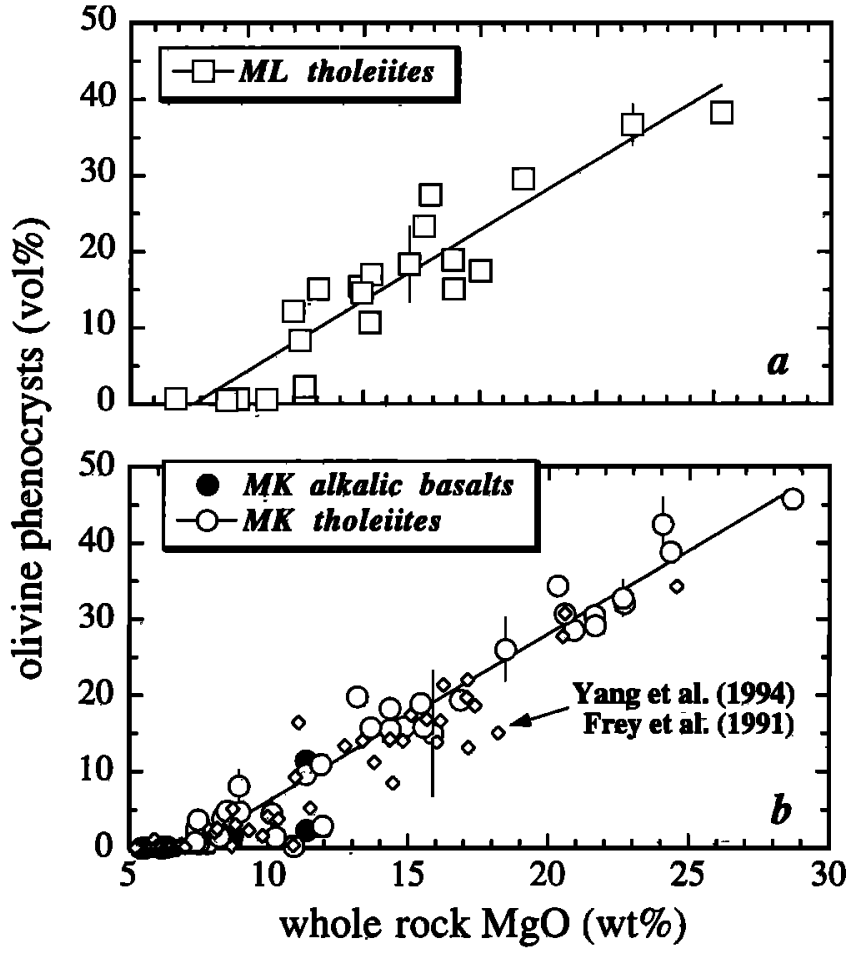

Figure 2. Modal olivine phenocryst content (this study) versus whole-rock $\mathrm{MgO}$ contents [Rhodes, this issue]. The $\mathrm{MgO}$ contents are normalized to $100 \mathrm{wt} \%$ on an anhydrous basis, with all $\mathrm{Fe}$ as $\mathrm{FeO}$. Vertical error bars indicate the range in olivine abundance in two thin sections from the same flow; symbols indicate average modal olivine abundances for these units. The solid lines are least-squares fits to the modal and compositional data. (a) Modal olivine phenocryst content in the ML tholeiites versus whole-rock $\mathrm{MgO}$ content in weight percent. Regression line: \% oliv $=-14.31+1.85$ (MgO, wt $\%), R=0.93$. (b) Modal olivine phenocryst content versus bulk-rock MgO content in MK tholeiites (open circles) and alkalic basalts (solid circles). Modal data for three thin sections were averaged for unit 105 and the horizontal bar equals $1 \sigma$ Open diamond symbols represent MK alkalic basalts and submarine tholeiites [Frey et al., 1991; Yang et al., 1994]. Regression line: \% oliv $=-15.77+2.19(\mathrm{MgO}$, wt \%), $R=$ 0.97 .

xenoliths noted in the core logs [HSDP, 1994]. With one exception (R177-9.7 is blocky and angular), the dunite xenoliths are roughly ellipsoidal in shape. Olivines in all of the xenoliths contain abundant spinel inclusions. Olivine grain sizes vary from inclusion to inclusion and in some cases within a particular inclusion; for example, olivines in R1779.7 are 1-2 mm in size, while R241-2.9 has a porphyroblastic texture with larger olivine grains (1-2 $\mathrm{mm}$ in size) surrounded by smaller olivines $(0.1-0.2 \mathrm{~mm}$ in size). For most of the samples, the contact between the xenolith and the groundmass is sharp; however, for R292-0.7, groundmass partially penetrates the xenolith. The xenoliths were prepared as thick polished mounts, so we have not determined whether the olivines in these samples are strained. However, it is likely that many of these olivines are strained based on previous studies of Hawaiian dunite xenoliths [Chen et al., 1992; Clague and Bohrson, 1991; Sen and Presnall, 1986] 
Table 2. Mean Bulk Compositions of the Most Magnesian ML and MK Tholeiites With Less Than 10 vol \% Modal Olivine, Calculated Primary Magma, and Estimates of the Bulk Composition of the MK Tholeiites that Comprise the HSDP Core

\begin{tabular}{|c|c|c|c|c|c|c|c|c|c|c|c|c|}
\hline & $\begin{array}{l}\text { mber of } \\
\text { nalyses }\end{array}$ & $\mathrm{SiO}_{2}$ & $\mathrm{TiO}_{2}$ & $\mathrm{Al}_{2} \mathrm{O}_{3}$ & $\mathrm{Cr}_{2} \mathrm{O}_{3}$ & $\mathrm{FeO}^{*}$ & $\mathrm{MnO}$ & $\mathrm{MgO}$ & $\mathrm{CaO}$ & $\mathrm{Na}_{2} \mathrm{O}$ & $\mathrm{K}_{2} \mathrm{O}$ & $\mathrm{P}_{2} \mathrm{O}_{5}$ \\
\hline $\mathrm{ML}_{12.4}$ & 2 & $50.4(4)$ & $1.77(9)$ & $12.0(1)$ & $0.10(1)$ & $11.4(6)$ & $0.18(1)$ & $12.4(2)$ & $9.3(1)$ & $2.1(1)$ & $0.30(6)$ & $0.18(3)$ \\
\hline $\mathrm{MK}_{11.5}$ & 4 & $49.6(5)$ & $2.32(10)$ & $12.1(2)$ & $0.09(2)$ & $11.3(2)$ & $0.17(1)$ & $11.5(5)$ & $10.2(5)$ & $2.1(1)$ & $0.37(6)$ & $0.23(2)$ \\
\hline $\mathbf{M K}_{\mathrm{p}}$ & & 48.46 & 2.05 & 10.72 & 0.18 & 11.27 & - & 15.76 & 9.00 & 1.85 & 0.33 & 0.20 \\
\hline $\mathrm{MK}_{\mathrm{B} 1}$ & & 48.6 & 2.2 & 11.1 & 0.12 & 11.5 & - & 14.2 & 9.4 & 2.0 & 0.3 & 0.2 \\
\hline $\mathrm{MK}_{\mathrm{B} 2}$ & & 48.7 & 2.3 & 11.4 & 0.11 & 11.5 & - & 13.6 & 9.6 & 2.0 & 0.3 & 0.2 \\
\hline $\mathrm{MK}_{\mathrm{B} 3}$ & & 48.8 & 2.3 & 11.5 & 0.11 & 11.5 & - & 13.2 & 9.7 & 2.1 & 0.3 & 0.2 \\
\hline
\end{tabular}

Data in weight percent from Rhodes [this issue]; number of analyses are the number of whole-rock compositions included in each mean; $\mathrm{ML}_{12.4}$ is the average of R55 and R114; $\mathrm{MK}_{11.5}$ is the average of R291, R298, R424, and R463. Values in parentheses represent 1 $\sigma$, i.e., 50.4(4) represents $50.4 \pm 0.4$. $\mathrm{MK}_{\mathrm{p}}$ is a primary melt calculated by adding $98 \%$ equilibrium olivine and $2 \%$ spinel in 0.5 wt $\%$ increments to $\mathrm{MK}_{11.5}$. The calculation was carried out along the QFM buffer at one bar and was stopped when the calculated equilibrium olivine reached Fo $0_{90.5}$. For each new liquid, the olivine-liquid $\mathrm{Fe}^{2+}-\mathrm{Mg} \mathrm{K}$ was calculated using the equation from Gee and Sack [1988], and the $\mathrm{Fe}^{3+} / \mathrm{Fe}^{2+}$ ratio of the liquid was calculated using the equation from Kilinc et al. [1983] with modified coefficients from Holloway et al. [1992]. At each step, temperature was calculated using equation (B2) of Langmuir et al. [1992] The composition of the spinel added to $\mathrm{MK}_{11.5}$ is the mean composition of spinel inclusions in olivine phenocrysts from the HSDP MK tholeiites; the composition is $2.05 \mathrm{TiO}_{2}, 14.53 \mathrm{Al}_{2} \mathrm{O}_{3}, 44.98 \mathrm{Cr}_{2} \mathrm{O}_{3}, 25.72 \mathrm{FeO}$, and $11.75 \mathrm{MgO}$ (all in wt $\%$ ), and was held constant throughout the calculation. $\mathrm{MK}_{\mathrm{B} 1}$ is the weighted bulk composition of all of the $\mathrm{MK}$ tholeites in the reference suite [Rhodes, this issue]. The bulk composition (wt \%) of each flow was weighted by the relative thickness of that flow (vesicle-free). MK $\mathrm{M}_{\mathrm{B} 2}$ denotes the weighted bulk composition for the MK tholeiites in the reference suite calculated from the weighted olivine phenocryst mode. Modal data from Table 1 were augmented with data from the core logs [HSDP, 1994]. The average core-log olivine modes from each unit were multiplied by 1.45 after correcting for vesicle abundance (the factor of 1.45 was based on a comparison between thin-section modes and core-log modes on the same flows). The integrated abundance of olivine in the core was then determined by weighting the olivine content of each flow by the flow thickness (after correcting for vesicle content). The weighted olivine abundance for all of the flows in the reference suite was then converted to MgO with the expression: wt $\% \mathrm{MgO}=7.6+0.431$ ( $\%$ oliv), $R=0.97$. The remaining oxides were calculated from oxide-MgO linear regressions. $\mathrm{MK}_{\mathrm{B} 3}$ is the weighted bulk composition of all of the MK tholeiites in the HSDP core. Modal olivine content of each flow (Table 1 and core logs, [HSDP, 1994]) was weighted by the relative thickness of that flow (vesicle-free). Weight percent oxides were calculated as described above.

\section{Olivine and Spinel Compositions}

Most olivine phenocrysts in the ML and MK lavas have cores that are unzoned or only slightly zoned. Olivine grains with reversely-zoned cores are rare in our population of analyzed olivines (three grains out of more than 100 grains analyzed; see also Garcia [this issue]). Such olivines are also rare in surface-collected and submarine-dredged MK and ML lavas [Garcia et al., 1995; Wilkinson and Hensel, 1988; Yang et al., 1994], in contrast to the tholeiites from Kilauea, where reversely-zoned olivine phenocrysts are relatively common [e.g., Clague et al., 1995]. Although some of these nearly homogeneous cores could reflect the orientation of the analyzed surface relative to the grain center [Pearce, 1984], it is probable that most of them either grew relatively slowly and/or from a large volume of liquid or were held at high temperatures after crystallization for a sufficient time to homogenize any pre-existing zonation. Phenocryst core compositions are summarized in histogram form in Figure 3, and representative analyses are reported in Table 3 . The ranges in core compositions are $\mathrm{Fo}_{80.4-90.7}$ (ML tholeiites) and $\mathrm{Fo}_{75.8-90.5}$ (MK tholeiites and alkalic basalts). Some thin sections from both volcanoes contain olivines that display nearly the entire range of observed core compositions. Olivines with core compositions in the range Fo 89-90.5 are present in tholeiitic lavas with a wide range of bulk MgO contents (9-30 wt \%). Olivines from submarine ML and MK tholeiites [Garcia et al., 1995; Yang et al., 1994] have distributions of forsterite content similar to olivines in tholeiites from the HSDP core. Olivine rims in all of the lavas are less than several hundred microns thick and display strong normal zoning. Olivine rim compositions in the ML and MK tholeiitic lavas from the drill core are $\mathrm{Fo}_{65-80}$. Olivine rims in the alkalic lavas have compositions that are $<\mathrm{Fo}_{60}$.

There are no systematic differences in forsterite contents of unstrained and strained olivine grains (each analyzed olivine was visually checked for strain features). In the nine analyzed ML tholeiites, mean forsterite contents of the cores of unstrained and strained grains are $87.3 \pm 3.0$ and $88.4 \pm 1.8 \mathrm{~mol} \mathrm{\%}$, respectively. For the ten analyzed MK tholeiites, the mean forsterite contents of unstrained and strained olivine cores are $86.7 \pm 2.8$ and $87.7 \pm 2.2 \mathrm{~mol} \%$; these means are $84.2 \pm 3.5$ and $85.6 \pm 0.4 \mathrm{~mol} \%$ in the MK alkalic lavas. A similar overlap in composition of unstrained and kink-banded olivines is also observed in surface-sampled picrites from Mauna Loa and in lavas dredged from Kilauea's submarine east rift [Clague and Denlinger, 1994; Wilkinson and Hensel, 1988].

Core compositions of olivine in the six MK dunite xenoliths are $\mathrm{Fo}_{78.3-89.2}$ (Figure 3d). Within a given xenolith, all olivines have essentially the same composition; based on seven to nine analyses per xenolith, the standard deviation of the olivine composition in each xenolith is $<1 \mathrm{~mol} \%$ Fo. Olivine grains in contact with groundmass have normallyzoned rims $-100-200 \mu \mathrm{m}$ thick. Although our sample population is not large, the more Fe-rich olivine compositions (Fo $78-85$ ) found in three of the xenoliths are uncommon in the population of olivine core compositions in the ML and MK tholeiites (Figures $3 \mathrm{a}$ and $3 \mathrm{c}$ versus $3 \mathrm{~d}$ ).

Figure $3 \mathrm{e}$ shows a histogram of olivine compositions from dunite xenoliths from alkalic lavas from Loihi and Hualalai [Chen et al., 1992; Clague, 1988; Clague and Bohrson, 1991] and post-erosional lavas from Koolau [Sen and Presnall, 1986]. The compositions of olivines in these xenoliths define an almost flat distribution with $93 \%$ of the analyses 

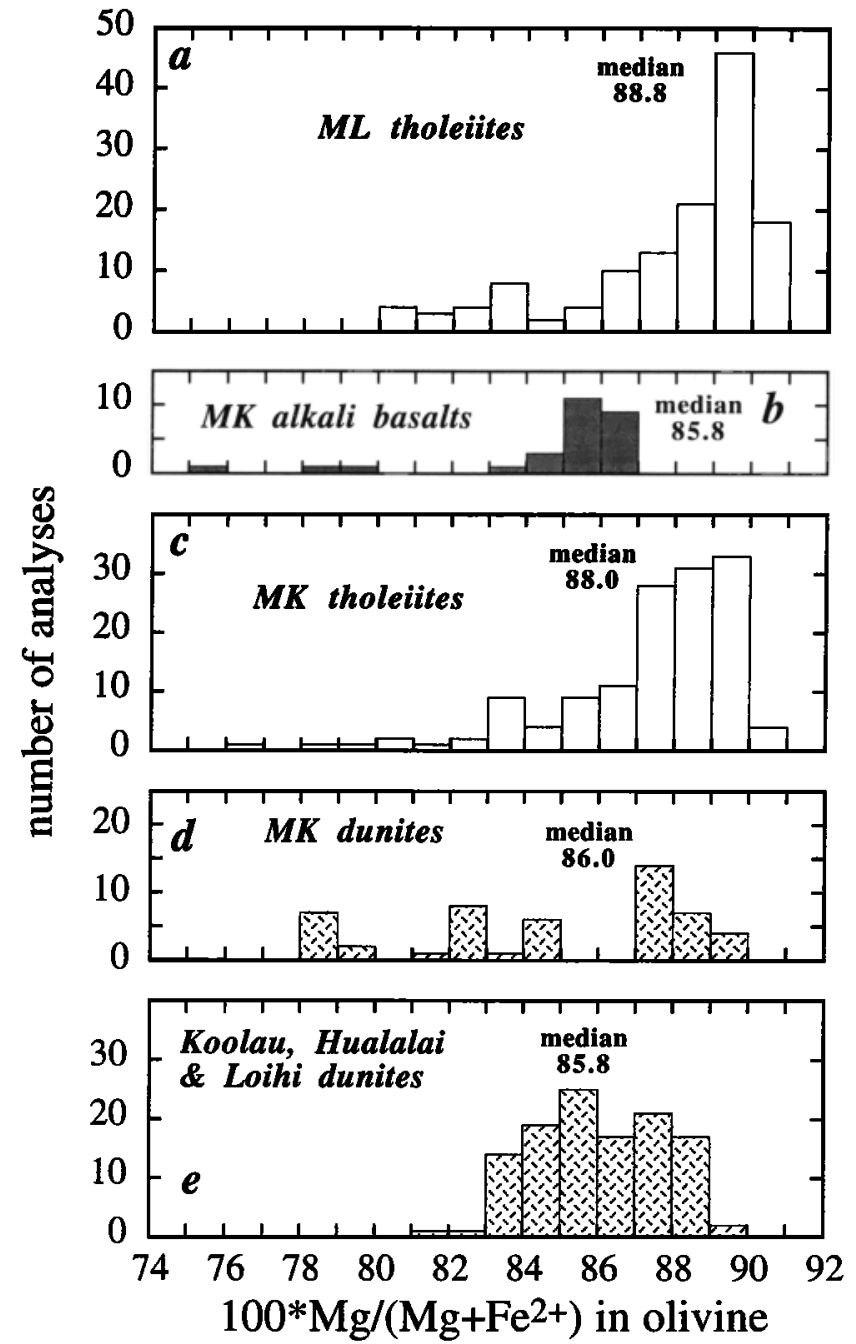

Figure 3. Histograms of $100 * \mathrm{Mg} /(\mathrm{Mg}+\mathrm{Fe}$ ) (molar) in the cores of olivine phenocrysts in (a) ML tholeiites, (b) MK alkalic basalts, (c) MK tholeiites, (d) olivines from MK dunite xenoliths, and (e) dunites from Koolau [Sen and Presnall, 1986], Hualalai [Chen et al., 1992; Clague and Bohrson, 1991], and Loihi [Clague, 1988]. Median forsterite contents are listed for each histogram.

falling between $\mathrm{Fo}_{83}$ and $\mathrm{Fo}_{89}$. This is in contrast to the skewed distributions of the phenocryst compositions from the HSDP tholeiites. Based largely on a comparison between spinel compositions in the xenoliths and those in alkalic lavas, Clague [1988] and Chen et al. [1992] concluded that the dunite xenoliths from Loihi and Hualalai are cumulates from alkalic magmas. Based also on a comparison of spinel compositions, Sen and Presnall [1986] interpreted the Koolau dunites as products of fractional crystallization of tholeiitic shield-building lavas. Note that the median forsterite contents of the Koolau, Hualalai, Loihi, and HSDP MK dunites are all more Fe-rich than the median forsterite contents of the cores of olivine phenocrysts in the ML and MK tholeiites. In addition, olivines with forsterite contents higher than $89 \mathrm{~mol} \%$ are uncommon in dunite xenoliths (Figures $3 \mathrm{~d}$ and $3 \mathrm{e}$ ) relative to their abundance in the populations of phenocrysts in tholeiites from the HSDP core (Figures $3 a$ and $3 c$ ).
Nickel abundances in the cores of olivine phenocrysts from the HSDP core are positively correlated with forsterite content. The most forsteritic olivines $\left(\mathrm{Fo}_{88-90.7}\right.$ ) contain 3000 $4000 \mathrm{ppm} \mathrm{Ni}$, whereas olivine cores with forsterite contents $\leq 80 \mathrm{~mol} \%$ have $<2000 \mathrm{ppm}$ Ni. Olivines from the alkalic lavas have $\mathrm{Ni}$ contents similar to those from the tholeiites, but at a given forsterite content, they plot in the lower half of the Ni-Mg\# band defined by the tholeiitic olivines. At a given forsterite content, strained and unstrained olivine phenocrysts in the HSDP lavas have similar ranges of Ni concentration. Nickel abundances in olivines from the MK dunite xenoliths also correlate with forsterite content and at the same forsterite content are roughly comparable to $\mathrm{Ni}$ abundances in olivine phenocrysts from the HSDP lavas.

Figure 4 compares the distribution of $\mathrm{CaO}$ contents (wt \%) in olivine phenocryst cores from the ML and MK lavas with those from the MK dunitic inclusions and from dunite xenoliths sampled at Koolau, Hualalai and Loihi [Chen et al., 1992; Clague, 1988; Clague and Bohrson, 1991; Sen and Presnall, 1986]. CaO contents in the phenocrysts in the tholeiites range from 0.18 to $0.42 \mathrm{wt} \%$, although $\sim 95 \%$ of the analyses are in the interval $0.18-0.30 \mathrm{wt} \%$. These $\mathrm{CaO}$ contents (i.e., $\sim 0.2-0.3$ wt \%) are consistent with low-pressure magmatic crystallization [Jurewicz and Watson, 1988]. Olivine phenocrysts in the MK alkalic basalts contain $0.20-0.35$ wt \% $\mathrm{CaO}$. Based on the distribution shown in Figure 4, they are typically slightly richer in $\mathrm{CaO}$ than olivines from the tholeiites, as expected based on the relationship between the olivine-liquid partition coefficient for $\mathrm{CaO}$ and temperature and olivine composition [Jurewicz and Watson, 1988; Synder and Carmichael, 1992] Among all of the phenocrysts, $\mathrm{CaO}$ contents display a weak inverse correlation with forsterite content. In the tholeiites and the alkalic basalts, there is complete overlap in the $\mathrm{CaO}$ contents of strained and unstrained olivines. The olivines in the dunite inclusions from the MK tholeiitic lavas have a bimodal distribution of $\mathrm{CaO}$ contents-olivines in one inclusion have $0.08-0.12 \mathrm{wt} \%$ $\mathrm{CaO}$ and olivines from the other five inclusion have $0.18-$ $0.32 \mathrm{wt} \% \mathrm{CaO}$. In contrast, $\mathrm{CaO}$ contents of olivines from most previously studied Hawaiian dunites are $\leq 0.20$ wt $\%$ (Figure 4d), consistent with crystallization under plutonic conditions based on compositions of olivines from known igneous environments [Simkin and Smith, 1970].

Representative analyses of spinels included in olivine phenocrysts and dunites are reported in Table 3 . Spinels in olivine phenocrysts are chromium-rich, with $\mathrm{Cr} \#$ (defined as molar $100 * \mathrm{Cr} /(\mathrm{Cr}+\mathrm{Al})$ ) of $59-72$ and $\mathrm{Mg} \#$ of $40-66$. Cr\# and Mg\# show a weak positive correlation (Figure 5). Spinel compositions from ML and MK tholeiites are indistinguishable, but those from MK alkalic basalts are at the low end of the observed range of $\mathrm{Cr}$ for a given $\mathrm{Mg \#}$. The compositions of spinels in strained and unstrained olivines are indistinguishable. The compositions of spinels from the MK dunites are also plotted in Figure 5. Although they extend to lower

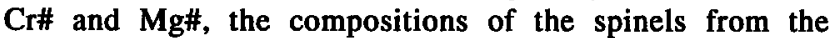
dunites overlap with those from the lavas and also show a positive correlation between $\mathrm{Cr} \#$ and $\mathrm{Mg \#}$. The dashed line in Figure 5 outlines the field of spinel compositions from other Hawaiian dunites [Chen et al., 1992; Clague, 1988; Clague and Bohrson, 1991; Sen and Presnall, 1986]; this field encompasses all but the most $\mathrm{Mg}$ - and $\mathrm{Cr}$-rich of the spinels from the lavas and the MK dunites. 
Table 3. Selected Olivine and Spinel Compositions From Hawaii Scientific Drilling Project Lavas and Dunite Xenoliths

\begin{tabular}{|c|c|c|c|c|c|c|c|c|c|c|c|c|c|}
\hline Thin section & Unit & Mineral & Notes & $\mathrm{SiO}_{2}$ & $\mathrm{TiO}_{2}$ & $\mathrm{Al}_{2} \mathrm{O}_{3}$ & $\mathrm{Cr}_{2} \mathrm{O}_{3}$ & $\mathrm{FeO}^{*}$ & $\mathrm{MnO}$ & MgO & $\mathrm{CaO}$ & $\mathrm{NiO}$ & Mg\# \\
\hline \multicolumn{14}{|c|}{ ML Lavas } \\
\hline \multirow[t]{2}{*}{ R68-1.25 } & 13 & sp & 1 & 0.08 & 1.07 & 14.0 & 48.2 & 22.7 & 0.25 & 13.1 & 0.00 & 0.17 & 61.1 \\
\hline & & oliv (st) & 2 & 40.1 & 0.01 & 0.04 & 0.23 & 11.5 & 0.18 & 48.2 & 0.24 & 0.38 & 88.2 \\
\hline \multirow[t]{4}{*}{ R130-3.5D } & 32 & sp & 3 & 0.09 & 1.02 & 14.5 & 49.5 & 20.6 & 0.24 & 13.9 & 0.00 & 0.25 & 64.1 \\
\hline & & oliv (st) & 4 & 40.2 & 0.01 & 0.05 & 0.19 & 9.67 & 0.12 & 49.6 & 0.21 & 0.45 & 90.1 \\
\hline & & sp & 5 & 0.04 & 2.28 & 15.3 & 40.0 & 29.8 & 0.24 & 11.6 & 0.00 & 0.21 & 52.9 \\
\hline & & oliv (un) & 6 & 39.5 & 0.03 & 0.02 & 0.16 & 14.0 & 0.15 & 46.0 & 0.26 & 0.33 & 85.4 \\
\hline \multirow[t]{2}{*}{ R133-7.85B } & 34 & sp & 7 & 0.08 & 1.30 & 18.1 & 44.8 & 20.3 & 0.21 & 14.7 & 0.01 & 0.26 & 66.2 \\
\hline & & oliv (un) & 8 & 40.7 & 0.01 & 0.04 & 0.27 & 9.45 & 0.12 & 49.3 & 0.21 & 0.46 & 90.3 \\
\hline \multicolumn{14}{|c|}{ MK Lavas } \\
\hline R160-6.8B & 47 & sp & 9 & 0.09 & 2.02 & 16.6 & 41.3 & 27.6 & 0.25 & 12.5 & 0.02 & 0.20 & 56.2 \\
\hline \multirow[t]{3}{*}{ R193-3.9B } & 69 & sp & 11 & 0.06 & 1.26 & 12.9 & 46.6 & 26.1 & 0.23 & 11.4 & 0.00 & 0.19 & 54.0 \\
\hline & & oliv (un) & 12 & 39.9 & 0.03 & 0.03 & 0.11 & 13.6 & 0.18 & 46.3 & 0.26 & 0.38 & 85.8 \\
\hline & & oliv (st) & 13 & 40.5 & 0.01 & 0.04 & 0.26 & 10.3 & 0.14 & 49.1 & 0.22 & 0.39 & 89.5 \\
\hline \multirow[t]{4}{*}{ R208-5.2B } & 75 & $\mathrm{sp}$ & 14 & 0.05 & 4.51 & 14.4 & 39.0 & 29.6 & 0.28 & 10.9 & 0.01 & 0.17 & 47.8 \\
\hline & & oliv (st) & 15 & 40.3 & 0.04 & 0.01 & 0.07 & 13.7 & 0.18 & 46.3 & 0.23 & 0.28 & 85.8 \\
\hline & & sp & 16 & 0.06 & 3.62 & 14.4 & 36.8 & 33.8 & 0.26 & 10.0 & 0.03 & 0.23 & 45.2 \\
\hline & & oliv (un) & 17 & 39.80 & 0.00 & 0.02 & 0.16 & 15.3 & 0.21 & 44.8 & 0.25 & 0.35 & 83.9 \\
\hline \multirow[t]{2}{*}{ R315-4.85B } & 132 & sp & 18 & 0.10 & 1.77 & 14.7 & 47.6 & 23.8 & 0.27 & 12.2 & 0.01 & 0.22 & 55.6 \\
\hline & & oliv (st) & 19 & 40.7 & 0.00 & 0.03 & 0.16 & 11.0 & 0.14 & 48.1 & 0.25 & 0.42 & 88.6 \\
\hline \multirow[t]{2}{*}{ R463-9.3B } & 224 & sp & 20 & 0.08 & 2.47 & 13.8 & 39.9 & 32.4 & 0.29 & 8.82 & 0.02 & 0.18 & 41.5 \\
\hline & & oliv (un) & 21 & 39.4 & 0.03 & 0.02 & 0.08 & 15.7 & 0.20 & 45.0 & 0.24 & 0.32 & 83.7 \\
\hline \multirow[t]{4}{*}{ R442-5.7B } & 208 & oliv (un) & 22 & 39.9 & 0.04 & 0.00 & 0.04 & 13.9 & 0.19 & 45.6 & 0.35 & 0.24 & 85.4 \\
\hline & & oliv (un) & 23 & 40.4 & 0.00 & 0.10 & 0.19 & 12.2 & 0.17 & 47.0 & 0.34 & 0.36 & 87.3 \\
\hline & & $\mathrm{sp}$ & 24 & 0.10 & 1.28 & 13.8 & 47.8 & 24.8 & 0.25 & 11.5 & 0.02 & 0.20 & 54.0 \\
\hline & & oliv (un) & 26 & 39.4 & 0.02 & 0.01 & 0.02 & 19.0 & 0.27 & 41.9 & 0.22 & 0.34 & 79.7 \\
\hline \multicolumn{14}{|c|}{ MK Dunites } \\
\hline \multirow[t]{2}{*}{ R177-9.7 } & & oliv & 27 & 40.2 & 0.00 & 0.00 & 0.01 & 12.2 & 0.14 & 47.4 & 0.10 & 0.31 & 87.4 \\
\hline & & $\mathbf{s p}$ & 28 & 0.04 & 2.63 & 19.0 & 38.6 & 25.5 & 0.25 & 13.7 & 0.00 & 0.24 & 60.0 \\
\hline \multirow[t]{2}{*}{ R225-8.2 } & & oliv & 29 & 38.8 & 0.02 & 0.01 & 0.06 & 20.2 & 0.26 & 41.1 & 0.19 & 0.29 & 78.4 \\
\hline & & sp & 30 & 0.15 & 8.82 & 10.8 & 18.7 & 51.5 & 0.29 & 7.97 & 0.01 & 0.20 & 32.7 \\
\hline \multirow[t]{2}{*}{ R292-0.7 } & & oliv & 31 & 40.7 & 0.03 & 0.03 & 0.07 & 10.6 & 0.15 & 48.3 & 0.23 & 0.32 & 89.1 \\
\hline & & $\mathbf{s p}$ & 32 & 0.16 & 1.47 & 14.8 & 48.1 & 21.4 & 0.21 & 14.1 & 0.01 & 0.13 & 63.9 \\
\hline
\end{tabular}

Notes: 1 , sp inclusion in oliv; 2 , oliv hosting sp inclusion; 3 , sp inclusion in oliv; 4 , oliv hosting sp inclusion; 5 , sp inclusion in oliv; 6 , oliv hosting sp inclusion; 7, sp inclusion in oliv; 8, oliv hosting sp inclusion; 9, sp inclusion in oliv; 10, oliv hosting sp inclusion; 11, sp inclusion in oliv; 12, oliv hosting sp inclusion; 13, oliv core; 14, sp inclusion in oliv; 15, oliv hosting sp inclusion; 16, sp inclusion in oliv; 17, oliv hosting sp inclusion; 18, sp inclusion in oliv; 19, oliv hosting sp inclusion; 20, sp inclusion in oliv; 21, oliv hosting sp inclusion; 22, oliv core; 23, interior of oliv \#22; 24, sp inclusion in oliv; 25 , oliv hosting sp inclusion; 26 , oliv core; 27 , oliv core; 28 , sp inclusion in oliv \#27; 29, oliv core; 30 , sp inclusion in oliv \#29; 31 , oliv core; 32, sp inclusion in oliv \$31. Abbreviations are oliv, olivine; sp, spinel; st, strained; un, unstrained. Determinations based on the presence or absence of strain features in the olivine, e.g., presence of kink-banding under crossed-polarized light. Dunite samples were found in the following flows: R177-9.7, unit 58; R225-7.1 and R225-8.2, unit 90; R239-5.1, unit 99; R241-2.9, unit 100; R292-0.7, unit 121. Xenoliths were prepared as polished mounts and the presence or absence of strain was not determined. $\mathrm{Mg} \#=100^{*} \mathrm{Mg} /\left(\mathrm{Mg}+\mathrm{Fe}^{2+}\right) ; \mathrm{Fe}^{2+}$ in the spinels calculated assuming charge-balance and $\mathrm{R}_{3} \mathrm{O}_{4}$ stoichiometry.

$\mathrm{TiO}_{2}$ contents and $\mathrm{Mg \#}$ for spinel inclusions in olivine phenocrysts are plotted in Figure 6. In the ML and MK lavas, these crystals have $1-4 \mathrm{wt} \% \mathrm{TiO}_{2}$. Spinels in the MK dunites define two populations; four of the inclusions contain spinels with $\mathrm{TiO}_{2}$ contents of $1-4 \mathrm{wt} \%$ and $\mathrm{Mg \#}$ of 45-66, and two inclusions contain spinels with $\mathrm{TiO}_{2}$ contents of 8-10 wt \% and $\mathrm{Mg \#}$ of 31-47. Some of the Ti-rich spinels plot outside the field of spinel compositions from the dunites from Koolau, Hualalai and Loihi [Chen et al., 1992; Clague, 1988; Clague and Bohrson, 1991; Sen and Presnall, 1986].

\section{Discussion}

\section{Do any of the Magnesian ML and MK Lavas} Represent Liquids?

The observation that $\mathrm{MgO}$-rich, olivine-phyric Hawaiian lavas define olivine control lines in MgO-oxide variation diagrams [e.g., Murata and Richter, 1966; Powers, 1955] has been used to infer that they are not liquids but mixtures of melts and varying proportions of olivine phenocrysts [e.g., Clague et al., 1995; Rhodes, 1988; Wright, 1971]. One test 


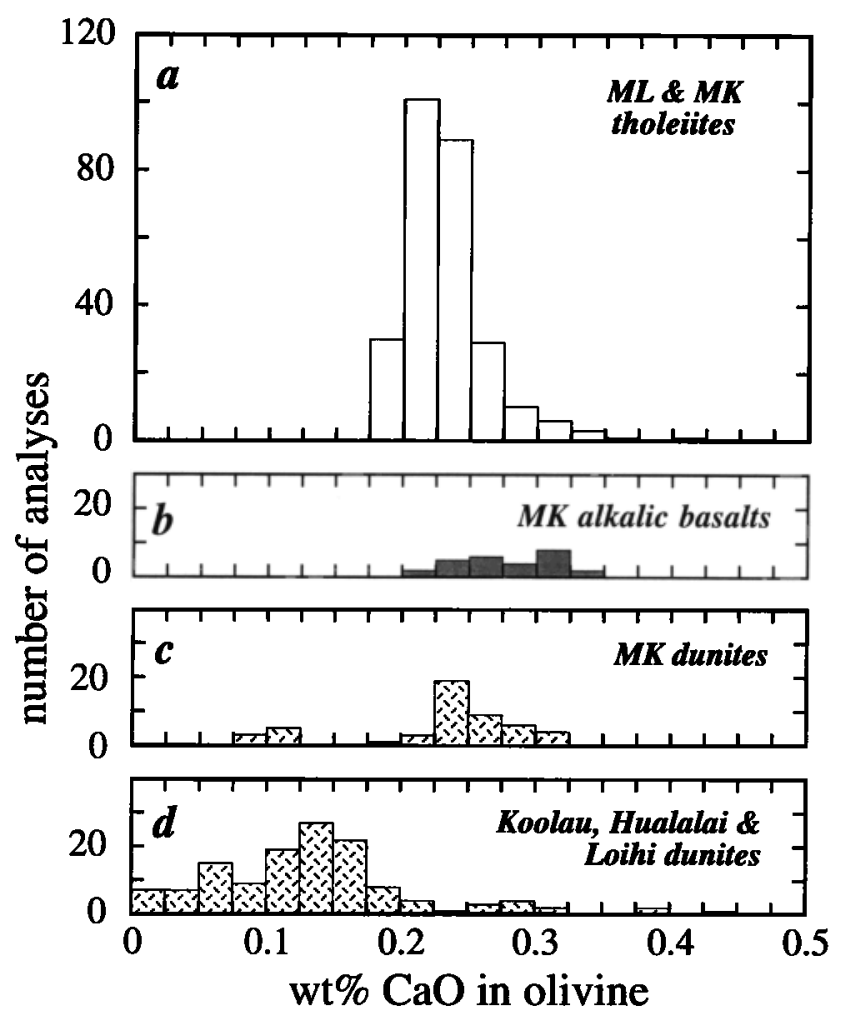

Figure 4. Histograms of $\mathrm{CaO}$ contents (wt \%) in the cores of olivine phenocrysts from ML and MK tholeiites and MK alkalic basalts and in olivines from MK dunite xenoliths and other Hawaiian dunites (references listed in Figure 3 caption).

for whether an olivine-rich magma represents a liquid involves comparing the most forsteritic phenocryst in the rock to the composition of the liquidus olivine calculated for that rock [Basaltic Volcanism Study Project, 1981]. Figure 7 plots the most magnesian olivine phenocrysts in individual HSDP lavas against whole-rock $\mathrm{Mg \# .} \mathrm{The} \mathrm{Mg \#} \mathrm{for} \mathrm{each} \mathrm{whole} \mathrm{rock} \mathrm{was}$ calculated after first calculating a liquidus $\mathrm{Fe}^{3+} / \mathrm{Fe}^{2+}$ at the QFM buffer using the equation of Kilinc et al. [1983] (updated coefficients from Holloway et al. [1992], temperature calculated using equation (B2) from Langmuir et al. [1992]); analyses of $\mathrm{Fe}^{3+} / \mathrm{Fe}^{2+}$ in Hawaiian glasses are consistent with crystallization near the QFM buffer [Byers et al., 1985; Carmichael, 1991]. The two dashed lines in Figure 7 show the $2 \sigma$ range of calculated liquidus olivine compositions for all of the whole-rock compositions. For each bulk composition, a calculated $\mathrm{Fe}^{2+}-\mathrm{Mg} \mathrm{K}$ was determined using the equation of Gee and Sack [1988]; $\mathrm{fO}_{2}$ was assumed to correspond to QFM. If the calculated composition of the liquidus olivine matches the most magnesian olivine observed in the lava, then the lava may represent a liquid composition. Although there are other interpretations, if the calculated liquidus olivine is more magnesian than the most magnesian olivine, then the lava has probably accumulated olivine.

For lavas with $\mathrm{Mg \#} \geq 70,(\mathrm{MgO} \geq 12.3 \mathrm{wt} \%)$, the maximum forsterite content of the olivine phenocrysts is roughly constant $\left(\sim \mathrm{Fo}_{89-90}\right)$. For these lavas, the most magnesian olivine composition matches the calculated liquidus olivine for $\mathrm{Mg \#}$ of 70-76, the exact value depending on the preferred $\mathrm{Fe}^{2+}-\mathrm{Mg}$ $K_{D}$ value. With a $K_{D}$ value of $0.29-0.31$, this indicates that the most magnesian olivines found in the HSDP lavas crystal-

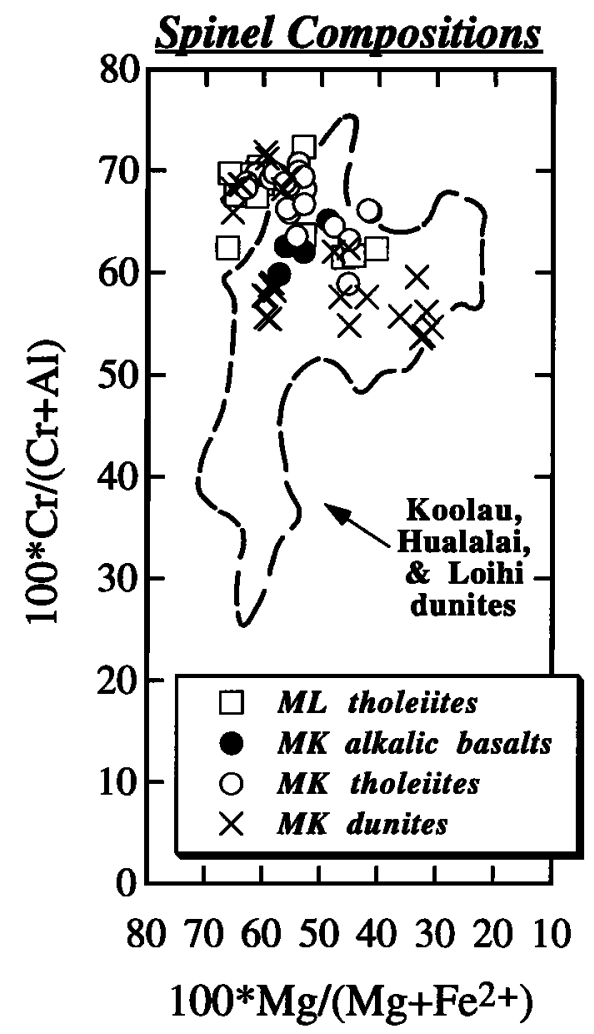

Figure 5. Compositions $\left(100 * \mathrm{Mg} /\left(\mathrm{Mg}+\mathrm{Fe}^{2+}\right)\right.$ (molar) versus $100 * \mathrm{Cr} /(\mathrm{Cr}+\mathrm{Al})$ (molar)) of spinel inclusions in the interiors of olivine phenocrysts in ML and MK lavas and in olivines in the MK dunitic xenoliths. $\mathrm{Fe}^{2+}$ in the spinels is calculated assuming charge-balance and $\mathrm{R}_{3} \mathrm{O}_{4}$ stoichiometry. Dashed line encloses the field for spinels from other Hawaiian dunites (references listed in Figure 3 caption).

lized from liquids with 15-17 wt \% MgO. For lavas with Mg\# $\geq 76$ ( $\mathrm{MgO} \geq 17 \mathrm{wt} \%$ ), the calculated liquidus olivines are more magnesian than the most magnesian observed olivines, strongly suggesting that these lavas have accumulated olivine phenocrysts. We cannot rule out the possibility that the lavas with 15-17 wt \% $\mathrm{MgO}$ represent liquids based on this line of reasoning. However, the abundance of olivine phenocrysts in these lavas (15-20 vol \%) and the presence of $\mathrm{Fo}_{89-90}$ olivines in all lavas with $\geq 12.3 \mathrm{wt} \% \mathrm{MgO}$ suggests that the compositions of these magnesian rocks reflect the addition of 5-20\% magnesian olivines to tholeiitic liquids with 7-12 wt \% MgO (now represented by the nearly aphyric lavas).

In two of the Mauna Kea lavas with $\mathrm{Mg \#} \mathrm{<70,} \mathrm{the} \mathrm{maximum}$ observed forsterite content in the olivine phenocrysts is less magnesian than what could crystallize from a liquid with the whole-rock Mg\# (i.e., the two points below the lower-dashed line in Figure 7). This most likely reflects the fact that we did not analyze enough olivine grains to sample the most Fo-rich olivines in these rocks. For some lavas with $\mathrm{Mg \#}<70$, the maximum observed forsterite content in olivine phenocrysts is more magnesian than what could crystallize from a liquid with the whole-rock Mg\# (i.e., the two points above the upper-dashed line in Figure 7). This.could reflect partial retention or entrainment of olivines crystallized earlier in the liquid-line-of-descent (i.e., not all early formed olivines were removed from the system by settling or other processes, or some early formed olivines were introduced into the residual 


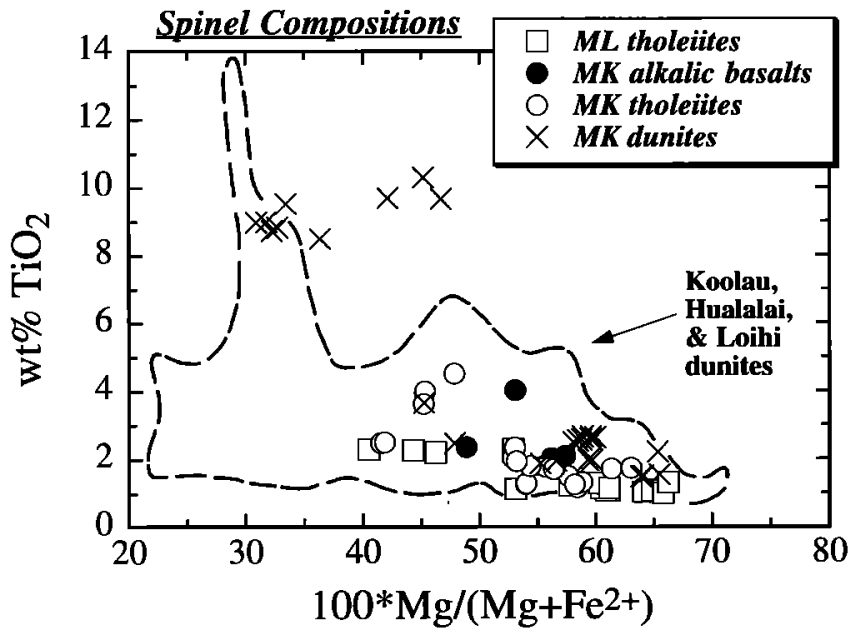

Figure 6. Weight percent $\mathrm{TiO}_{2}$ versus $100 * \mathrm{Mg} /\left(\mathrm{Mg}+\mathrm{Fe}^{2+}\right)$ (molar) in spinel inclusions from olivine phenocrysts in the ML and MK lavas and in olivines from MK dunite xenoliths. The dashed line outlines the field for spinels from other Hawaiian dunites (references listed in Figure 3 caption).

magma). It is important to stress that entrained olivines may be genetically related to the host magma even though they are not in $\mathrm{Fe}^{2+}-\mathrm{Mg}$ equilibrium with the liquid. Other interpretations of the magnesian phenocrysts in these relatively lowMg\# lavas include crystallization under anomalously oxidizing conditions, magma mixing (i.e., these magnesian olivine cores crystallized from one of the mixing end members), or the presence of exotic xenocrysts. Settling rates calculated for olivine phenocrysts in Hawaiian magmas [Clague et al.,

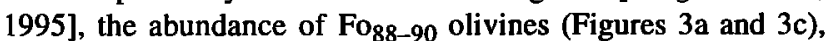
measured $\mathrm{Fe}^{3+} / \mathrm{Fe}^{2+}$ in Hawaiian glasses [Byers et al., 1985; Carmichael, 1991], and the rarity of reversely-zoned olivines all suggest that the magnesian olivines are either cognate grains entrained during the eruption process or xenocrysts.

\section{Parental Liquids and the Weighted Bulk Composition of the HSDP Core}

In this section, we compare the integrated bulk composition of the MK tholeiitic lavas in the drill core with a model parental MK composition ( $\mathrm{MK}_{\mathrm{p}}$, Table 2). The purpose of this comparison is to evaluate the average flux of olivine out of MK magma chamber(s). As discussed above, lavas in the drill core with $>12 \mathrm{wt} \% \mathrm{MgO}$ have probably accumulated olivine during the eruption process. Based on our modal olivine-MgO regressions (Figure 2), the erupting liquids (now represented by groundmass) typically had 7-8 wt \% $\mathrm{MgO}$, although slightly higher $\mathrm{MgO}$ contents are consistent with the most magnesian aphyric lavas in the drill core. As noted by Clague and Denlinger [1994], among others, a substantial amount of olivine must crystallize from a parental magma in equilibrium with $\sim \mathrm{Fog}_{0}$ olivine to produce magmas with 7-8 wt \% $\mathrm{MgO}$. The question that we address is how much of this olivine remains at depth within the volcanic plumbing system as opposed to being erupted. If the MK portion of the drill core has an integrated composition that is similar to or only slightly less magnesian than the estimated composition of the parental magma, then on average, the $\mathrm{MgO}$-poor liquids retain or en-

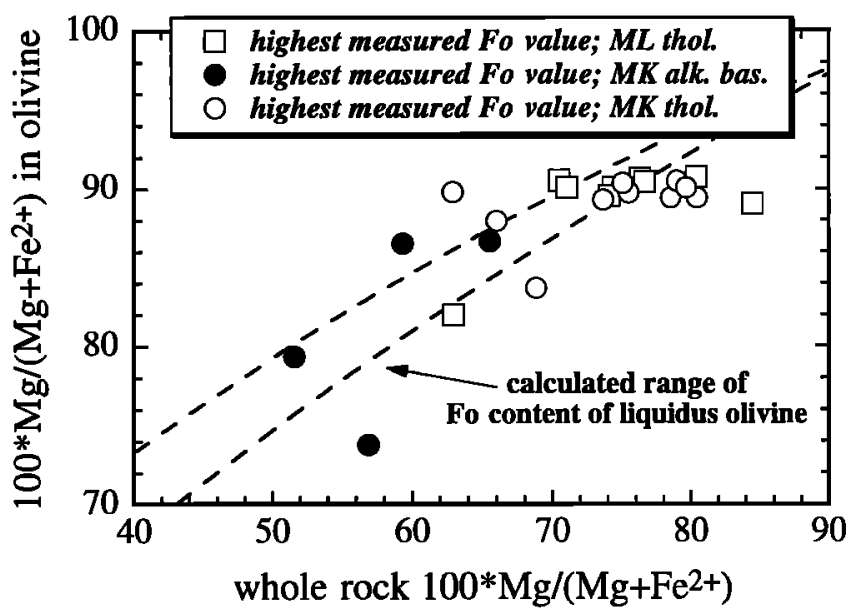

Figure 7. Forsterite content of the most magnesian olivines measured in ML and MK lavas versus the corresponding whole-

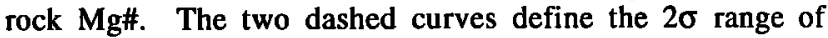
olivine compositions calculated to be in equilibrium with each of the bulk-rock compositions at QFM. The olivine-liquid $\mathrm{Fe}^{2+}-\mathrm{Mg} \mathrm{K} \mathrm{K}_{\mathrm{D}}$ calculated from the expression of Gee and Sack [1988], whole-rock $\mathrm{Fe}^{3+} / \mathrm{Fe}^{2+}$ calculated using the expression of Kilinc et al. [1983] with modified coefficients from Holloway et al. [1992], temperatures calculated using equation (B2) of Langmuir et al. [1992]. Uncertainties on the calculated olivine composition reflect a $6 \%$ uncertainty on the olivineliquid $\mathrm{Fe}^{2+}-\mathrm{Mg} \mathrm{K} \mathrm{K}_{\mathrm{D}}$, and $0.4 \%$ and $3.8 \%$ uncertainties on the $\mathrm{MgO}$ and $\mathrm{FeO}$ contents, respectively. All three uncertainties are $1 \sigma$.

train most of the olivine phenocrysts produced during the evolution of these liquids, and little olivine accumulates within the magmatic system. Although we have only considered the MK lavas in the following calculations, the ML lavas are also MgO-rich and have similar parental liquid compositions, so we expect that the results will apply to both sets of lavas.

Starting with our estimate of the most magnesian liquid composition in the MK suite $\left(\mathrm{MK}_{11.5}\right)$, we calculated the composition of a parental liquid that could crystallize Fog0.5 at its liquidus, the most magnesian olivine composition found in the MK tholeiites. The composition of this primitive MK magma was calculated by adding $98 \%$ equilibrium olivine and $2 \%$ average spinel (see footnote to Table 2 ) in $0.5 \mathrm{wt} \%$ increments to $\mathrm{MK}_{11.5}$ until the resultant liquid is calculated to be in equilibrium with Fo90.5 olivine. The magnesian liquid calculated in this way contains $15.8 \mathrm{wt} \% \mathrm{MgO}$ (Table 2) and reflects the addition of $12 \mathrm{wt} \%$ olivine to $\mathrm{MK}_{11.5}$. The integrated olivine composition is Fog9. This calculated liquid composition is similar to other estimates of primary Hawaiian tholeiites [Chen, 1993; Clague et al., 1991; Garcia et al., 1995; Wright, 1971]. We have also "reversed" our olivine-addition calculation and determined that $20 \mathrm{wt} \%$ olivine must fractionate from $\mathrm{MK}_{\mathrm{p}}$ to produce a liquid with $8 \mathrm{wt} \% \mathrm{MgO}$. This liquid composition would plot at the olivine-poor end of the array in Figure $2 \mathrm{~b}$ and is probably similar to the composition of the groundmass in many of the olivine-phyric lavas. The integrated composition of the 20 wt \% olivine is Fo87.4, and is nearly identical to the calculated average composition of accumulated olivine phenocrysts $\left(\mathrm{Fo}_{87.7 \pm 0.4}\right)$ in the MK 


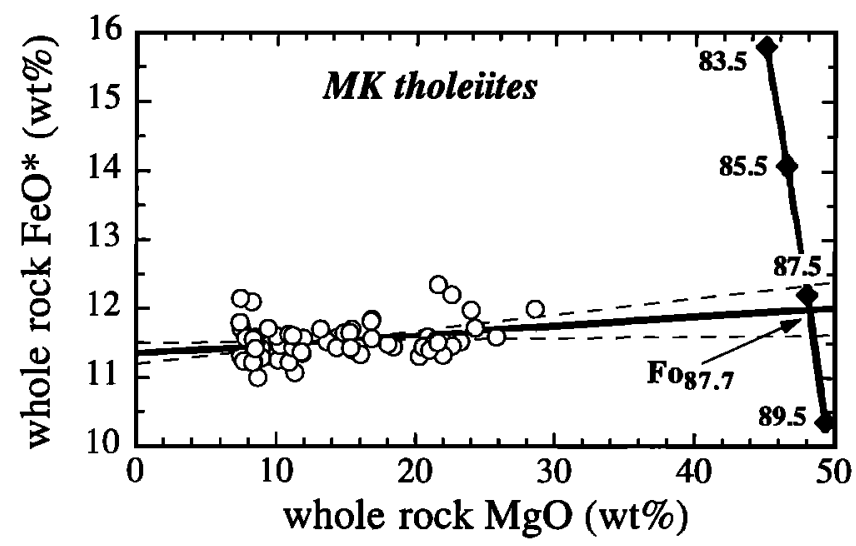

Figure 8. Whole-rock $\mathrm{FeO}^{*}$ versus $\mathrm{MgO}$ (wt \%) in the MK tholeiites. The nearly horizontal solid line is the unweighted least-squares regression fit to the whole-rock $\mathrm{FeO}^{*}$-MgO contents (i.e., the olivine control line); dashed lines represent $2 \sigma$ uncertainties on the calculated slope. The nearly vertical line shows the $\mathrm{FeO}$ and $\mathrm{MgO}$ contents of olivines with varying Mg\#; numbers beside the solid diamonds are forsterite contents. The intersection of the olivine control line with the olivine composition line defines the average accumulated olivine composition in the MK tholeiites. This average composition is $\mathrm{Fo}_{87.7 \pm 0.4}(2 \sigma)$.

tholeiites (Figure 8). Accumulated olivine compositions calculated for lavas from Kilauea are $\sim \mathrm{Fo}_{88}$ [Clague et al., 1995; Murata and Richter, 1966; Wright, 1971].

Figure 9 compares the composition of our model parental MK magma with our estimates of the integrated composition of the tholeiitic lavas from the MK portion of the HSDP core on a plot of $\mathrm{MgO}$ versus $\mathrm{SiO}_{2}$ (both in wt \%). For reference, we also plotted the MK tholeiites. We used two approaches to calculate the integrated composition of the tholeiitic lavas in the MK reference suite-weighting the whole-rock composition of each flow by the relative thickness of the flow on a vesicle-free basis (estimate 1); and determining the weighted abundance of olivine in all of the flows (vesicle-free; Table 1 and $[H S D P, 1994])$, converting the weighted olivine abundance to whole-rock $\mathrm{MgO}$ content using the relationship between these two quantities (Figure 2), and finally calculating the remaining oxides from oxide-MgO linear regressions (estimate 2). Both of these estimates are listed in Table 2. The integrated $\mathrm{MgO}$ content calculated using the major-element data is $14.2 \mathrm{wt} \%$; the integrated $\mathrm{MgO}$ content calculated using modal olivine abundances is $13.6 \mathrm{wt} \%$. The tholeiitic flows of the reference suite constitute $\sim 57 \%$ of the total thickness of tholeiite lavas from the MK portion of the HSDP core. Combining data from Table 1 with olivine modes from $H S D P$ [1994] for all of the remaining MK tholeiites, we also calculated the weighted bulk composition for the entire tholeiitic section; the MgO content of this estimate is $13.2 \mathrm{wt} \%$ (Table 2). Although it is difficult to assess the uncertainties in these calculations, the results indicate that the MK tholeiites are, on average, very magnesian lavas, and that the weighted composition of the core is only slightly less magnesian than our estimate of the parental MK magma. The differences in $\mathrm{MgO}$ content between the estimated bulk compositions of the tholeiitic section and $\mathrm{MK}_{\mathrm{p}}$ range from 1.6-2.6 wt \% MgO, and correspond to 4-7 wt $\%$ Fo $_{87.7}$ olivine. These calculations,

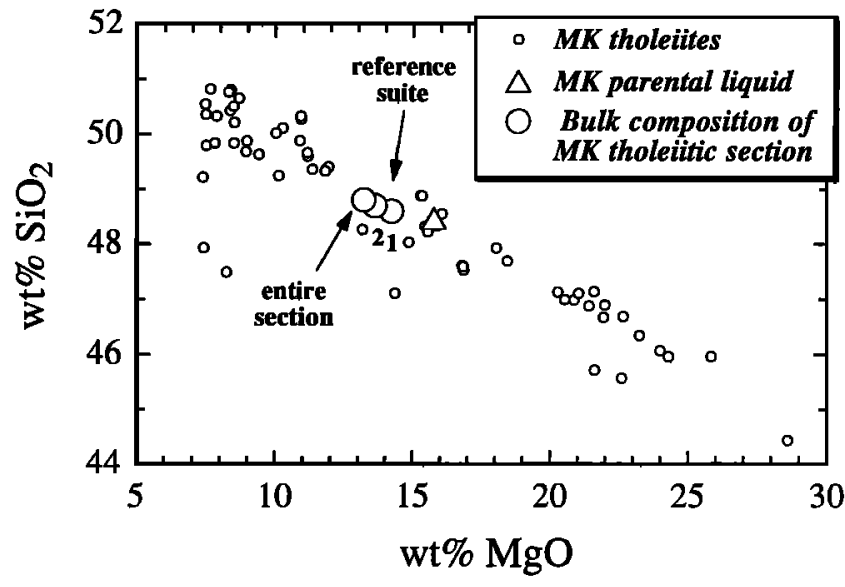

Figure 9. Weight percent $\mathrm{SiO}_{2}$ versus $\mathrm{MgO}$ in the $\mathrm{MK}$ tholeiites [Rhodes, this issue], in $\mathrm{MK}_{\mathrm{p}}$ (Table 2), and in three estimates of the weighted bulk composition of the MK tholeiites in the HSDP drill core (Table 2). Estimate (1) denotes the weighted bulk composition of the MK tholeiitic flows that comprise the HSDP reference suite [Rhodes, this issue]; wholerock composition of each lava was weighted by flow thickness after correcting the thickness of each flow for its vesicle content (vesicle abundances in Table 1 were augmented with data from the core logs [HSDP, 1994]). Estimate (2) denotes the bulk composition calculated from the weighted modal olivine abundance in the MK tholeiites from the reference suite. Modal data from Table 1 were augmented with data from the core logs [HSDP, 1994]. The average core-log olivine modes from each unit were multiplied by 1.45 after correcting for vesicle abundance (the factor of 1.45 was based on a comparison between thin-section modes and core-log modes on the same flows). The integrated abundance of olivine in the core was then determined by weighting the olivine content of each flow by the flow thickness (after correcting for vesicle content). The weighted olivine abundance for all of the flows in the reference suite was then converted to $\mathrm{MgO}$ with the expression: wt $\% \mathrm{MgO}=7.6+0.431$ ( $\%$ oliv), $R=0.97$. The remaining oxides were calculated from oxide-MgO linear regressions. The weighted $\mathrm{SiO}_{2}$ and $\mathrm{MgO}$ contents of all of the MK tholeiites (entire section) were calculated from the weighted olivine abundances in all of the tholeiitic lavas (Table 1 and core-log data $[H S D P, 1994])$ following the procedure described above.

combined with the results of our olivine-addition and fractionation calculations suggest that, as a whole, the MK tholeiitic lavas represent magmas that have entrained $42-80 \%$ of the olivine that crystallized from their parental liquids.

The presence of cumulate dunitic xenoliths in Hawaiian magmas [Clague, 1987; Jackson, 1968] indicates that some olivine accumulation does occur within magma chambers and/or conduit systems in Hawaii. Based on calculations of the amount of olivine crystallization required to produce an average Kilauean lava from an estimated parental liquid, Clague and Denlinger [1994] proposed that 10-22 wt \% olivine is stored in the Kilauea magma chamber. Our calculations suggest that, during the later stage of tholeiitic eruptions of MK, only 4-7 wt\% olivine is permanently deposited at depth in the MK magmatic system. In addition to providing a constraint on the nature of volcano growth, this conclusion bears indirectly on the question of whether the strained olivine phenocrysts in the MK lavas are "cognate" or "exotic" (i.e., 
xenocrysts). In particular, the similarity between the integrated composition of the MK tholeiites and our estimate of a parental MK magma, indicates that, on average, the olivines present in the lavas correspond in abundance and composition to the olivines that crystallize at depth from such parental magmas. The observed aphyric lavas and the groundmass of the phyric lavas represent the products of this fractional crystallization. This, in turn, suggests that most of the olivine phenocrysts in a given flow are closely related to the erupting liquid (i.e., the groundmass). Although other interpretations are possible, we speculate that these phenocrysts crystallized from magnesian liquids closely-related to (and similar in composition to) the liquids that were parental to the groundmass in the MK tholeiites; the deformation observed in these olivine phenocrysts could have occurred during a short residence time in the cumulate pile or on conduit walls prior to entrainment during eruption.

It is clear that concentration of olivine either by entrainment or accumulation played a significant role in the petrogenesis of most of the HSDP samples. This is not a new or surprising result since Hawaiian tholeiites have long been known to lie along olivine control lines [Murata and Richter, 1966; Powers, 1955; Wright, 1971]. However, the question of whether the substantial numbers of strained olivine phenocrysts in these flows represent "cognate" or "exotic" grains is a relatively new one. These deformed olivines have generally been interpreted in the HSDP lavas and in other Hawaiian suites as a random sampling of disaggregated cumulate dunites underlying the volcano [Clague and Denlinger, 1994; Garcia, this issue; Helz, 1987; Yang et al., 1994], although other interpretations are possible [Wilkinson and Hensel, 1988]. However, as pointed out above, such an origin by entrainment does not necessarily indicate an "exotic" origin for these grains, whether they are strained or unstrained. As we suggest above, they may be recently crystallized products of the same magmatic system that produced the entraining liquid, and thus the evolved groundmass and the phenocrysts can still be closely related. The answer to the question of the relation of these grains to the liquid in which they are entrained is not of narrow petrographic importance since several isotopic measurements (e.g., He and Os isotopes [Hauri et al., this issue; Kurz et al., this issue] and oxygen isotopes [Eiler et al., this issue]) have either been made on olivine separates $(\mathrm{He}, \mathrm{O})$ or are dominated by an olivine component (Os). If the olivine grains were substantially exotic and unrelated to the groundmass, it would strongly influence the interpretation of these isotopic measurements. However, as noted by Eiler et al., [this issue] and Kurz et al., [this issue], $\mathrm{O}$ and $\mathrm{Pb}$ isotopes and $\mathrm{He}$ and $\mathrm{Nd}$ isotopes are correlated in the HSDP samples. For example, the correlations between $\delta^{18} \mathrm{O}$ and ${ }^{206} \mathrm{~Pb} /{ }^{204} \mathrm{~Pb}$ and between ${ }^{3} \mathrm{He} /{ }^{4} \mathrm{He}$ and ${ }^{143} \mathrm{Nd} /{ }^{144} \mathrm{Nd}$ in the $\mathrm{MK}$ tholeiites are significant at $>95 \%$ confidence level (Spearman rank-order correlation coefficients are -0.72 and -0.70 , respectively). Since the $\mathrm{He}$ and $\mathrm{O}$ isotope ratios are measured on olivine separates and $\mathrm{Nd}$ and $\mathrm{Pb}$ isotopes are carried nearly exclusively in the groundmass, these correlations would be difficult to understand if the olivine grains were truly exotic in the sense of being unrelated to the groundmass. Although this does not rule out a non-negligible fraction of such exotic olivines in the overall population (which would contribute noise to the overall correlations between $\mathrm{He} / \mathrm{Os} / \mathrm{O}$ isotopes versus $\mathrm{Nd} / \mathrm{Sr} / \mathrm{Pb}$ isotopes), it does support the view that most of the olivines crystallized either from the host liquid or from very closely related liquids.

\section{Conclusions}

The ML and MK lavas recovered by the Hawaii Scientific Drilling Project include aphyric to highly olivine-phyric basalts. All of the recovered ML lavas are tholeiitic, but at the top of the MK section, seven out of the 10 flows are alkalic (all the remaining MK flows are tholeiites). Plagioclase and augite phenocrysts are rare in the ML and MK tholeiites, while the MK alkalic basalts can have up to 4 vol \% plagioclase phenocrysts. Every thin section of ML and MK drill core lavas with a significant abundance of olivine contains some deformed olivine grains, and in the more olivine-phyric lavas, olivines with kink-bands and undulating extinction can comprise approximately $50 \%$ of the total olivine phenocrysts in the rock. There are no systematic differences in composition between the strained and unstrained olivines in the ML and MK lavas. Olivine core compositions in the ML and MK tholeiites span forsterite contents of 80.4-90.7 and 76.3-90.5 mol $\%$, and median values are 88.8 and $88.0 \mathrm{~mol} \%$. Spinel inclusions in both the strained and unstrained olivines are chromerich ( $\mathrm{Cr} \# \sim 59-72$ ) and relatively magnesian (Mg\# 40-66). Dunites are rare in the recovered lavas; six centimeter-sized dunite xenoliths from five MK flows have olivine compositions in the range $\mathrm{Fo}_{78.3-89}$. Within a given xenolith, all olivines have approximately the same composition.

Forsteritic olivines $\left(\mathrm{Fo}_{89-90}\right)$ are present in lavas that contain between 9 and $30 \mathrm{wt} \% \mathrm{MgO}$. A comparison of the most Fo-rich olivine phenocrysts in each of the analyzed flows with olivine compositions calculated from whole-rock $\mathrm{FeO}$ and $\mathrm{MgO}$ contents indicates that the $\mathrm{ML}$ and $\mathrm{MK}$ lavas with $>12 \mathrm{wt} \% \mathrm{MgO}$ have accumulated olivine. Based on whole-rock $\mathrm{FeO}^{*}$ and $\mathrm{MgO}$ contents for the MK tholeiites, the average composition of this accumulated olivine is $\mathrm{F}_{87.7}$. The MgO content of our calculated parental MK magma is 15.8 wt \%. This liquid is in equilibrium with Fo90.5, the most magnesian olivine composition found in the MK tholeiites. The $\mathrm{MgO}$ contents of our three estimates of the integrated composition of the tholeiitic lavas in the MK section of the core vary from 14.2-13.2 wt \%. Taken as a whole, the MK tholeiites are very magnesian and olivine-rich lavas. The similarity in composition between the integrated MK tholeiitic section of the core and the calculated parental magma suggests that the MK tholeiites have, on average, entrained most of the olivine that crystallized from their parental liquids. This in turn suggests that olivine phenocrysts in a given flow are closely related to the magma that entrained them. This is consistent with the observation that none of the major- and minor-element data collected on the olivines and their spinel inclusions require an exotic origin for the strained olivine phenocrysts, and with the observed correlations between isotopic systems measured on olivine separates and isotopic systems dominated by groundmass. These isotopic correlations would be difficult to understand if a large fraction of the olivine grains in a given lava were unrelated to the groundmass.

Acknowledgments. We would like to thank all those who assisted with core logging during the active phase of the drilling project. Don DePaolo, Ron Fodor, and Mike Garcia 
provided thorough reviews of the manuscript. This work was supported by NSF grant EAR-9117588. Caltech Division of Geological and Planetary Sciences contribution 5557.

\section{References}

Armstrong, J.T., Quantitative analysis of silicate and oxide minerals: comparison of Monte Carlo, ZAF and $\phi(p z)$ procedures, in Microbeam Analysis-1988, edited by D.E. Newbury, pp. 239-246, San Francisco Press, San Francisco, Calif., 1988.

Basaltic Volcanism Study Project, Basaltic Volcanism on the Terrestrial Planets, 1286 pp., Pergamon, Tarrytown, N. Y., 1981.

Bates, R.L., and J.A. Jackson, Glossary of Geology, 788 pp., Am. Geol. Inst., Alexandria, V., 1987.

Byers, C., M. Garcia, and D. Muenow, Volatiles in pillow rim glasses from Loihi and Kilauea volcanoes, Geochim. Cosmochim. Acta, 49, 1887-1896, 1985.

Carmichael, I.S.E., The redox state of basic and silicic magmas: A reflection of their source region?, Contrib. Mineral. Petrol., 106, 129-141, 1991.

Chayes, F., Petrographic Modal Analysis, 113 pp. John Wiley, New York, 1956

Chen, C.H., D.C. Presnall, and R.J. Stern, Petrogenesis of ultramafic xenoliths from the 1800 Kaupulehu flow, Hualalai volcano, Hawaii, J. Petrol., 33, 163-202, 1992.

Chen, C.Y., High-magnesian primary magmas from Haleakala Volcano, east Maui, Hawaii: petrography, nickel, and major-element constraints, J. Volcanol. Geotherm. Res., 55, 143-153, 1993.

Clague, D.A., Hawaiian xenolith populations, magma supply rates, and development of magma chambers, Bull. Volcanol.,49, 577-587, 1987.

Clague, D.A., Petrology of ultramafic xenoliths from Loihi Seamount, Hawaii, J. Petrol., 29, 1161-1186, 1988.

Clague, D.A., and W.A. Bohrson, Origin of xenoliths in the trachyte at Puu Waawaa, Hualalai volcano, Hawaii, Contrib. Mineral. Petrol., $108,439-452,1991$

Clague, D.A., and R.P. Denlinger, Role of olivine cumulates in destabilizing the flanks of Hawaiian volcanoes, Bull. Volcanol., 56, 425-434, 1994

Clague, D.A., W.S. Weber, and J.E. Dixon, Picritic glasses from Hawaii, Nature, 353, 553-556, 1991.

Clague, D.A., J.G. Moore, J.E. Dixon, and W.B. Freisen, Petrology of submarine lavas from Kilauea's Puna ridge, Hawaii, J. Petrol., 36 (2), 299-349, 1995.

Donaldson, C.H., An experimental investigation of olivine morphology, Contrib. Mineral. Petrol., 57, 187-213, 1976.

Eiler, J.M., J.W. Valley, and E.M. Stolper, Oxygen isotope ratios in olivine from the Hawaii scientific drilling project, J. Geophys. Res., this issue.

Frey, F.A., M.O. Garcia, W.S. Wise, A. Kennedy, P. Gurriet, and F. Albarede, The evolution of Mauna Kea volcano, Hawaii: Petrogenesis of tholeitic and alkalic basalts, J. Geophys. Res., 96, 14,347-14,375, 1991.

Garcia, M., Petrography and olivine and glass chemistry of lavas from the Hawaii Scientific Drilling Project, J. Geophys. Res., this issue.

Garcia, M.O., T.P. Hulsebosch, and J.M. Rhodes, Olivine-rich basalts from the southwest rift zone of Mauna Loa volcano: Implications for magmatic processes and geochemical evolution, in Mauna Loa Revealed: Structure, Composition, History, and Hazards, Geophys. Monogr. Ser., vol. 92, edited by J.M. Rhodes, and J.P. Lockwood, pp. 219-239, AGU, Washington, D.C., 1995.

Gee, L.L., and R.O. Sack, Experimental petrology of melilite nephelinites, J. Petrol., 29, 1233-1255, 1988.

Hauri, E.H., J.C. Lassiter, and D.J. DePaolo, Osmium isotope systematics of drilled lavas from Mauna Loa, Hawaii, J. Geophys. Res., this issue.

Hawaii Scientific Drilling Project (HSDP), Core-Logs, edited by E.M. Stolper, and M.B. Baker, 471 pp., Cal. Inst. of Technol., Pasadena, 1994.

Helz, R.T., Diverse olivine types in lava of the 1959 eruption of Kilauea volcano and their bearing on eruption dynamics, U. S. Geol. Surv., Prof. Pap., 1350, 691-722, 1987.
Hofmann, A.W., and K.P. Jochum, Source characteristics derived from very incompatible trace elements in Mauna Loa and Mauna Kea basalts, Hawaii Scientific Drilling Project, J. Geophys. Res., this issue.

Holloway, J.R., V. Pan, and G. Gudmundsson, High-pressure fluidabsent melting experiments in the presence of graphite: Oxygen fugacity, ferric/ferrous ratio and dissolved $\mathrm{CO}_{2}$, Eur. J. Mineral., 4, 105-114, 1992

Jackson, E.D., The character of the lower crust and upper mantle beneath the Hawaiian Islands, Proc. Int. Geol. Congr., 23rd, 135$150,1968$.

Jurewicz, A.J.G., and E.B. Watson, Cations in olivine, Part 1: Calcium partitioning and calcium-magnesium distribution between olivines and coexisting melts, with petrologic applications, Contrib. Mineral. Petrol., 99, 176-185, 1988.

Kilinc, A., I.S.E. Carmichael, M.L. Rivers, and R.O. Sack, The ferricferrous ratio of natural silicate liquids equilibrated in air, Contrib. Mineral. Petrol., 83, 136-140, 1983.

Kurz, M.D., T.C. Kenna, J.C. Lassiter, and D.J. DePaolo, Helium isotopic evolution of Mauna Kea volcano: First results from the $1 \mathrm{~km}$ drill core, J. Geophys. Res., this issue.

Langmuir, C.H., E. Klein, and T. Plank, Petrological systematics of midocean ridge basalts: Constraints on melt generation beneath ocean ridges, in Mantle Flow and Melt Generation at Mid-Ocean Ridges, Geophys. Monogr. Ser., vol 71, edited by J.P. Morgan, D.K. Blackman, and J.M. Sinton, pp. 183-280, AGU, Washington, D.C., 1992.

Lassiter, J.C., D.J. DePaolo, and M. Tatsumoto, Isotopic evolution of Mauna Kea volcano: Results from the initial phase of the Hawaii Scientific Drilling Project, J. Geophys. Res., this issue.

Murata, K.J., and D.H. Richter, The settling of olivine in Kilauea magma as shown by lavas of the 1959 eruption, Am. J. Sci., 264, 194-203, 1966.

Pearce, T.H., The analysis of zoning in magmatic crystals with emphasis on olivine, Contrib. Mineral. Petrol., 86, 149-154, 1984.

Powers, H.A., Composition and origin of basaltic magma of the Hawaiian Islands, Geochim. Cosmochim. Acta, 7, 77-107, 1955.

Rhodes, J.M., Geochemistry of the 1984 Mauna Loa eruption: implications for magma storage and supply, J. Geophys. Res., 93, 4453-4466, 1988.

Rhodes, J.M., Geochemical stratigraphy of lava flows sampled by the Hawaii Scientific Drilling Project, J. Geophys. Res., this issue.

Sen, G., and D.C. Presnall, Petrogenesis of dunite xenoliths from Koolau Volcano, Oahu, Hawaii: Implications for Hawaiian volcanism, $J$. Petrol., 27, 197-217, 1986.

Simkin, T., and J.V. Smith, Minor-element distribution in olivine, $J$. Geol., 78, 304-325, 1970.

Synder, D.A., and I.S.E. Carmichael, Olivine-liquid equilibria and the chemical activities of $\mathrm{FeO}, \mathrm{NiO}, \mathrm{Fe}_{2} \mathrm{O}$, and $\mathrm{MgO}$ in natural basaltic melts, Geochim. Cosmochim. Acta, 56, 303-318, 1992.

Wilkinson, J.F.G., Mauna Loan and Kilauean tholeiites with low 'ferromagnesian-fractionated' $100^{*} \mathrm{Mg} /\left(\mathrm{Mg}+\mathrm{F}^{\mathrm{e} 2}+\right)$ ratios: Primary liquids from the upper mantle?, J. Petrol., 32, 863-907, 1991.

Wilkinson, J.F.G., and H.D. Hensel, The petrology of some picrites from Mauna Loa and Kilauea volcanoes, Hawaii, Contrib. Mineral. Petrol., 98, 326-345, 1988.

Wright, T.L., Chemistry of Kilauea and Mauna Loa lava in space and time, U. S. Geol. Surv., Prof. Pap., 735, 40 pp., 1971.

Yang, H.-J., F.A. Frey, M.O. Garcia, and D.A. Clague, Submarine lavas from Mauna Kea volcano, Hawaii: Implications for Hawaiian shield-stage processes, J. Geophys. Res., 99, 15,577-15,594, 1994.

M.B. Baker and E.M. Stolper, Division of Geological and Planetary Sciences, California Institute of Technology, Pasadena CA, 91125. (email: mikeb@expet.gps.caltech.edu; ems@expet.gps.caltech.edu)

S. Alves, Institut de Physique du Globe de Paris, 4 place Jussieu, 75252 Paris Cedex 05, France. (e-mail: alves@ipgp.jussieu.fr)

(Received June 13, 1995; revised December 27, 1995; accepted January 17, 1996.) 